\title{
Orta Doğu Bölgesi Enerji Kaynaklarının 21. Yüzyıl Dünya Ekonomisi İçin Stratejik Önemi
}

\author{
Hüseyin ALTAY* \\ Ulaş NUGAY**
}

Özet

20. yüzyılda ülkeler açısından en stratejik girdi olmaya başlayan enerji kaynakları, bu önemini giderek daha da artırmaktadır. Enerjiye olan bağımlılı̆̆ın ve talebin bu oranda artmasına karşılık enerji kaynakları da hızla azalmaktadır. Bu durum tüm dikkatlerin enerji bölgelerine yoğunlaşmasına neden olmuştur. Bu bölgelerin başında da Orta Doğu gelmektedir. Bu kapsamda çalışmanın amacı, Orta Doğu enerji kaynaklarının 20 yüzyılda olduğu gibi 21. yüzyılda da dünya ekonomisi açısından önemini açıklamaktır. Bu amaç çerçevesinde, çalışmanın ilk kısmında Orta Doğu ve stratejik önemi hakkında bilgiler verilmiştir. İkinci kısımda ise, bölgenin dünyaya oranla petrol ve doğalgaz rezervleri, üretim ve tüketim değerleri incelenmiştir. Son kısımda da küresel güçlerin Orta Doğu politikaları ve bölge ülkelerle ilişkileri ı̧̧ı̆̆ında Orta Doğu bölgesinin 21. yüzyıldaki stratejik önemi ortaya konmaya çalışılmıştır.

Anahtar Kelimeler: Orta Doğu, Enerji, Petrol, Doğalgaz

\section{Strategic Importance of Energy Sources of Middle East Region for the 21 ${ }^{\text {st }}$ Century World Economy}

\section{Abstract}

The importance of energy sources which started to become the most strategic input for the countries in the 20th century gradually increases. Despite of the increase of demand and dependence to the energy at this ratio, energy resources speedily decrease. This situation caused that all the attentions focused on energy regions. Middle East is one of the most important of these regions. Within this framework, this study aims to explain the importance of Middle East energy sources of 21st century with regards to the world economy as was in the 20th century. In accordance with this purpose, information about Middle East and its strategic importance were given in the first part. In the second part, consumption and production values, petro-

\footnotetext{
*Yrd. Doç. Dr., Bilecik Şeyh Edebali Üniversitesi İ.İ.B.F. İktisat Bölümü, huseyin.altay@bilecik.edu.tr

** Bilecik Şeyh Edebali Üniversitesi, S.B.E, İktisat Bölümü, ulas_nugay@hotmail.com
} 
leum and natural gas reserve of the region in proportion to world were examined. In the last part, Middle East policies of global powers and strategic importance of Middle East in the 21st century in the light of their relations with the countries in the region were tried to be revealed.

Key Words: Middle East, Energy, Petroleum, Natural Gas

\section{Giriş}

Özellikle 1973 ve 1979 yıllarında yaşanan petrol şokları ve bunu takip eden fiyat artışları, tüm dünya ülkelerinde enerji girdisini ekonomik büyüme ve kalkınmanın en önemli faktörü haline getirmiştir (ETKB, 1984: 105). Bu dönemde, Kraft ve Kraft (1978)'in enerji tüketimi ve ekonomik büyüme üzerine yapmış oldukları öncü çalışma ve sonrasında yapılan diğer çalışmalar enerjinin ekonomik büyüme ve kalkınmanın en stratejik girdisi olduğunu ortaya koymuştur. Özellikle son 50 yıla ait dünya enerji tüketimi ve üretim verileri de incelendiğinde, dünyada gerçekleştirilen üretim çıtı düzeyi ile enerji talebi arasında bir paralelik olduğu açıkça görülmektedir. Ayrıca, ayrı ayrı tüm ülkelerin üretim çıktı düzeyleri, dolayısıyla ekonomik büyüme ve kalkınma oranlarıyla enerji talepleri ve tüketimleri arasında çok yakın bir ilişkinin varlığ 1 da bir çok çalışmada ispatlanmıştır (Eden ve diğ., 1982: 29). Bu kapsamda, ekonomik büyüme ve kalkınma konusunda enerjinin stratejik önemi ve buna bağlı tüm enerji sorunlarının çözümlenmesi gereği tüm gelişmiş, gelişmekte olan ve az gelişmiş ülkelerin öncelikli sorunu haline gelmiştir (Banks, 2000: 23).

Günümüzde birincil enerji kaynaklarına olan bağımlılık ve talep giderek artarken, mevcut enerji rezervleri de aynı hızla azalmaktadır. Bu önemli sorun, zengin enerji kaynaklarının bulunduğu bölgelerin önemini daha da artırırken, aynı zamanda bu bölgeleri dünya gündeminin ilk sırasına taşımaktadır. Bu bölgelerin başında da Orta Doğu gelmektedir. Enerjinin üretim, uluslararası rekabet, büyüme, kalkınma ve dolayısıyla ülkelerin bölgesel ya da küresel güç olma konularında en stratejik girdi olması 21. yüzyılda da Orta Doğu'nun önemini daha da artıracaktır.

20. yüzyılın Orta Doğu'sunun şekillenmesinde enerji politikaları etkin rol oynamıştır. Enerjinin üretim alanları ile tüketim alanlarının farklı ülkeler olması özellikle hegemon güçlerin bu bölgede söz sahibi olmaya çalı̧̧malarına, gerek kendi aralarında gerekse bölge güçleriyle siyasi, ekonomik işbirliği kurmasına, çıkarların uyuşmaması durumunda ise çatışmalara neden olmuştur. Bu kapsamda çalışmanın amacı Orta Doğu bölgesi enerji kaynaklarının 21. yüzyıl dünya ekonomisi için önemini ortaya koymaktır. Analizlerde Orta Doğu enerji kaynaklarının görünümü, güncel veri- 
ler ele alınarak incelenmekte ve bu kaynaklarının günümüz konjonktüründe oluşturduğu ekonomik ve stratejik önem ifade edilmektedir. Yapılan çalışma, yıllardır zengin kaynaklara sahip olduğu bilinen Orta Doğu coğrafyasının günümüz dünyasında ne denli yüksek miktarlarda enerjiye sahip olduğunu ifade etmek amacıyla önem taşımaktadır. Bu amaç çerçevesinde, çalışmanın ilk kısmında Orta Doğu ve stratejik önemi hakkında bilgiler verilmiştir. İkinci kısımda ise, bölgenin dünyaya oranla petrol ve doğalgaz rezervleri, üretim ve tüketim değerleri incelenmiştir. Son kısımda da küresel güçlerin Orta Doğu politikaları ve bölge ülkeleriyle ilişkileri ışığında Orta Doğu bölgesinin ve sahip olduğu enerji kaynaklarının 21. yüzyıldaki stratejik ve ekonomik önemi ortaya konmaya çalışılmıştır.

\section{Ortadoğu'nun Stratejik Önemi}

Orta Doğu kavramının genel olarak tek bir tanımı bulunmamaktadır. Orta Doğu ile ilgili bugüne kadar birbirinden farklı birçok tanımlama yapılmıştır. Bölge ile ilgili yapılan araştırmalarda her araştırmacının ilgilendiği alanlara göre dar veya geniş kapsamlı tanımlamalar yapılmıştır. Dar kapsamda "Ortadoğu; Batıda Mısır, kuzeyde Türkiye, doğuda İran, güneyde ise Suudi Arabistan'dan Yemen'e uzanan Arap Yarımadasını çevreleyen ve ortada Suriye, Lübnan, Ürdün, İsrail ve Filistin'in yer aldığı coğrafya olarak tanımlanabilir"( Arı, 2004: 25). Çalışmada ele alınan Orta Doğu kavramı, bu tanım kapsamında incelenirken, enerji kaynakları bakımından yapılan bölgesel değerlendirmelerde ülkeler bazında ifade edildiğinde Suriye, Irak, İran, Ürdün, Lübnan, Suudi Arabistan, B.A.E, Katar, Kuveyt, Umman, Yemen, Mısır ve Sudan ülkelerinden oluşan Orta Doğu coğrafyası temel alınmıştır. Bu ele alım sürecinde, Bp verilerinin Orta Doğu olarak ifade ettiği kapsam temel alınmış, çalışma içerisindeki enerji kaynaklarının dağılımı, belirtilen coğrafya üzerinden analiz edilmiştir.

$\mathrm{Bu}$ kapsamda değerlendirmeye alınan Ortadoğu'nun tarihine bakıldığında öncelikle bu bölgenin en dikkat çekici özelliklerinin başında her dönem bir çatışma bölgesi olduğu görülür. Ortadoğu dinlerin kesişme noktası olduğundan kültürel ve tarihi zenginlikler barındırmış, tarih boyunca çatışmaların yaşandığı bir bölge olmaktan kurtulamamıştır. Kıtaların birleşme noktasında yer alması, önemli geçitlerin bu bölgede yer alması Ortadoğu'nun önemini daha da arttırmış ve yakın tarih küresel aktörlerin bu bölgedeki güç mücadelelerine sahne olmuştur. Özellikle 20 . yüzyılın başında petrolün insan hayatına girmesi bu süreci daha da hızlandırmıştır. Petrolün sadece aydınlanma aracı olarak görülmesinden çıkarak ısınma ve otomobil sanayiinde kullanılması ile petrolün artan 
önemi, dönemin küresel aktörlerini petrol kaynaklarına yönlendirmiş ve Ortadoğu'daki petrol kaynaklarının bol oluşu tüm dünyanın gözünü bu bölgeye çevirmesine, petrol üzerine stratejiler belirlemelerine neden olmuştur. Ülkeler petrole kolay ve sorunsuz ulaşmak amacıyla sürekli yeni stratejiler ortaya koymuşlardır. Davutoğlu (2001:333)'na göre de “Petrolün uluslararası ekonomik ve politik güçler açısından taşıdığı hayati önem bu doğal kaynağa dayalı bir stratejik planlamanın geliştirilmesini zorunlu kılmıştır. Öyle ki petrol uluslararası politikanın modern dönemdeki iki önemli çatışma alanı olan jeopolitik ve ekonomi politiğin kesişim alanında son derece belirleyici bir rol oynamaya başlamıştır".

Orta Doğu'nun petrol bakımından sahip olduğu zenginliğin boyutu esas olarak İkinci Dünya Savaşından sonra keşfedilmiştir. Bu dönemden sonra Orta Doğu petrolleri uzunca bir süre çok uluslu petrol şirketlerinin hâkimiyeti altında kalmıştır (Özel,2003:6). Bu bağlamda, çok uluslu şirketlerin uluslararası politikaları çoğu zaman etkilediği ve kimi zaman da devletleri yönlendirdiği ifade edilebilir. "Batılı petrol şirketlerinin Orta Doğu petrollerinin üzerindeki kontrolüne karşı ilk ve en önemli hareket Petrol İhraç Eden Ülkeler Birliği olan Organization of Petroleum Exporting Countries (OPEC)'in 1960 yılında kurulmasıyla gerçekleşmiştir"(Acar vd., 2007: 35- 36). Bu gelişmelerin yanında Ortadoğu'nun diğer bir özelliği diyebileceğimiz nokta ise bölge ülkelerinin yaşadığı çatışmalar ve zayıf demokrasidir. Bölgede meydana gelen Arap- İsrail Savaşı, bölge ülkelerinde görülen askeri darbeler, İran-Irak savaşı, ABD'nin Basra harekâtı ve körfez savaşları yakın dönemde Ortadoğu'da meydana gelen ve hafızalarda kalan karışıklıklar olarak ortaya çıkmaktadır. Bu çatışmaların ve liderlik mücadelelerinin temelinde ise bölgenin jeopolitik ve jeostratejik önemi yatmaktadır. Dünyada enerjiye olan ihtiyacın giderek artmaya devam etmesi, enerjinin bölgesel ya da küresel güç olma mücadelelerinin en stratejik unsuru olması 21. yüzyılda da hegemon güçlerin Orta Doğu enerji kaynaklarına olan ilgisini daha da artıracaktır.

\section{Dünya Enerji Görünümü ve Orta Doğu}

Dünya enerji kaynaklarının her yerde eşit dağılmaması ve belirli bölgelerde çok belirli bölgelerde az olması enerji ticaretini ortaya çıkarmıştır. $\mathrm{Bu}$ ticaret hacmi içerisinde en çok talep edilen ve tüketimi yapılan enerji kaynağı ise hala petrol'dür. 


\section{Şekil 1: Dünya Enerji Tüketiminin Birincil Kaynaklara Göre} Dağılımı (2011-\%)

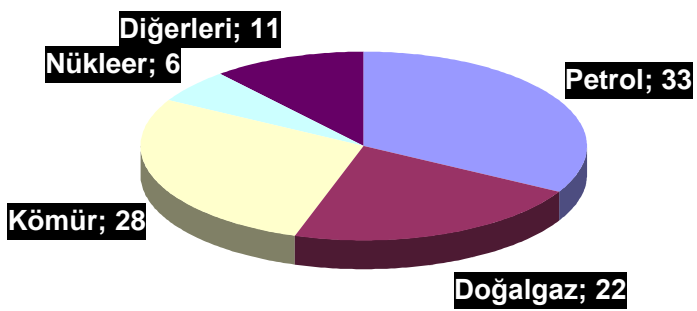

Kaynak: (EPDK, 2012: 2)

Dünya enerji tüketiminin kaynaklara göre dağılımında petrol 2011 yılında \% 33 ile ilk sırada yer almıştır. Petrolün ardından ise \% 28 ile kömür tüketimi gelmektedir. Yine ayn yılda toplam tüketimin \% 22'si ise doğalgazdan karşılanmıştır. Nükleer enerjinin toplam tüketimdeki payı \% 6 olmuştur. Diğer enerji kaynaklarının oranı ise \% 11'dir. Enerjinin elde edildiği kaynaklar her geçen gün çeşitlense bile kullanılan farklı birincil enerji kaynakları içerisinde petrol kullanımı hala önemli bir yer tutmaktadır (Acar vd.,2007: 3).

\section{Şeki 2:1990-2030 Dönemi Dünya Enerji Tüketimi Görünümü(Milyon Ton)}

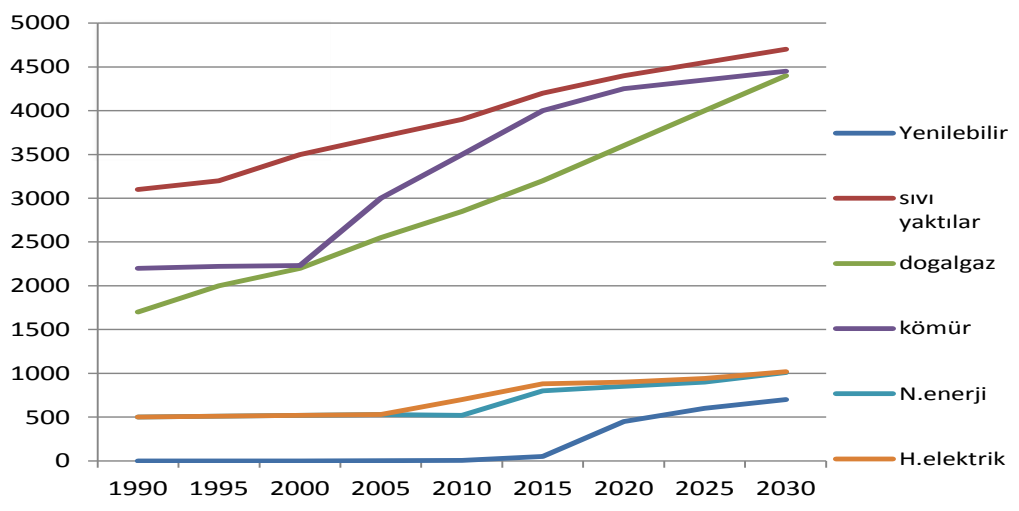

Kaynak: (TPAO,2010:2) 
Şekil 2' de gördüğü üzere enerji tüketiminde 20. yüzyılla beraber kullanımı yaygınlaşan petrol gün geçtikçe önem kazanırken, 2030 yılına doğru pazar payında küçük daralmalar beklense de en çok tüketilen enerji kaynağı olmaya devam edecektir. Kömür ise 2000'li yıllardan itibaren artış eğilimine girmiş ve bu artış hızının 2020'den itibaren yavaşlaması öngörülmektedir. 2030 yılına doğru kömür tüketimindeki artışın durması beklenilmektedir. Bununla beraber doğalgaz ise tüketimi en çok artacak enerji kaynağı olarak tahmin edilmektedir ve 2030 yılına kadar yapılan bu analizde kullanımında aralıksız artış beklenilmektedir.

Enerji kaynaklarının tüketiminin dağılımında gelişmiş ve gelişmekte olan ülkeler büyük rol oynamaktadır. Bu payda özellikle ABD, Çin gibi küresel güçler ve Hindistan, Güney Kore gibi gelişmekte olan ülkelerin payı büyüktür.

Tablo 1:Ülkelere Göre Birincil Enerji Tüketimi (2010-\%)

\begin{tabular}{llll}
\hline ÇİN & 20,3 & KANADA & 2,6 \\
ABD & 19 & G. KORE & 2,1 \\
RUSYA F. & 5,8 & BREZILYA & 2,1 \\
HINDİSTAN & 4,4 & AB & 14,4 \\
JAPONYA & 4,2 & ORTADOĞU & 5,8 \\
\hline & & DİĞER ÜLK. & $\mathbf{1 8 , 7}$ \\
\hline
\end{tabular}

Kaynak: (BP,2010: 40)

Tablo 1'de görüldüğü üzere 2010 yılının enerji tüketiminde en yüksek pay \% 20,3 ile Çin'e aittir. ABD ise \% 19 ile ikinci sırada yer almaktadır. $A B D$ ve Çin'i Rusya, Hindistan, Japonya, Kanada, Güney Kore ve Brezilya gibi ülkeler izlemektedir. Orta Doğu ülkelerinin toplam enerji tüketimindeki payı ise \% 5,8'dir. Orta Doğu ülkelerinin toplam tüketimi ancak Rusya'nın toplam tüketimine denk gelmektedir. Son olarak $\mathrm{AB}^{\prime}$ nin enerji tüketimindeki oranı ise \% 14,4'tür. Çin, ABD, Rusya, Hindistan, Japonya ve AB ülkelerinin toplamının \%68,1 olması bu ülkeler açısından Orta Doğu'nun önemini daha da artırmaktadır.

\section{Dünya Petrol Rezervleri Ve Orta Doğu}

Dünyada en çok tüketilen birincil enerji kaynağı olan petrol, ülkelerin ekonomik gelişimi için önem arz etmektedir. Petrolün bulunduğu bölgeler jeostratejik önem kazanmakta, petrol ihtiyacı olan ülkeler için çekim alanı haline gelmektedir. Dünyadaki bölgelere bakıldığında ise petrol rezervlerinin en çok olduğu bölgenin Orta Doğu olduğu dikkat çekmektedir. 


\section{Şekil 3:Bölgelere Göre İspatlanmış Petrol Rezervi(2010-\%)}

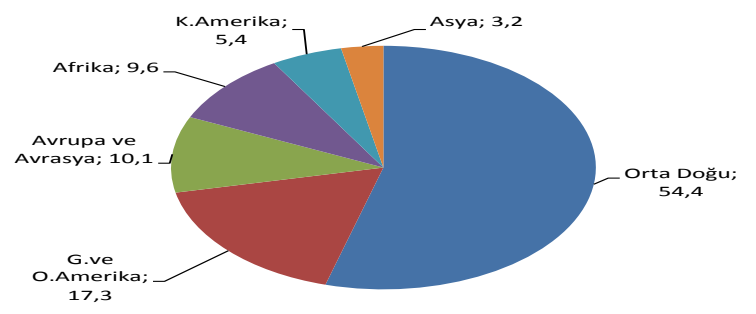

Kaynak: ( TPAO,2010: 4)

Şekil 3'teki verilere göre Orta Doğu bölgesi tek başına dünya petrol rezervlerinin \% 54,4'üne sahiptir ve bu özelliğiyle ilk sırada yer almaktadır. Petrol rezervinde Orta Doğu'yu \% 17,3 ile Güney ve Orta Amerika, \% 10,1 ile Avrupa ve Avrasya bölgeleri izlemektedir. Orta Doğu bölgesinin dünyadaki petrol rezervlerinin yarısından fazlasını elinde bulundurması bu bölgenin dünya için önemini ortaya koymaktadır. Petrol rezervlerinin ülkelere göre dağılımına bakıldığında da Orta Doğu ülkelerinin ilk sıralarda yer aldığı görülmektedir

Tablo 2:Ülkelere Göre Petrol Rezervleri(2010-\%)

\begin{tabular}{ll}
\hline SUUDI ARABISTAN & 19,1 \\
VENEZUELA & 15,3 \\
IRAN & 9,9 \\
\hline IRAK & 8,3 \\
KUVEYT & 7,3 \\
B.A.E & 7,1 \\
RUSYA FEDERASYONU & 5,6 \\
ABD & 2,2 \\
ÇİN & 1,1 \\
HINDİSTAN & 0,7 \\
AB & 0,5 \\
\hline TOPLAM & 77,1 \\
\hline
\end{tabular}

Kaynak: (BP,2011: 6)

2010 yılı verilerine göre petrol rezervinde dünyada ilk sırayı Suudi Arabistan \%19,1 ile almaktadır. İkinci sırada ise Venezuela \%15,3 ile yer almaktadır. İran \%9,9, Irak \%8,3, Kuveyt \%7,3, Birleşik Arap Emirlikleri 
(BAE) $\% 7,1$ ve Rusya Federasyonu \%5,6'lik paya sahip ülkelerdir. Bu ülkelerden Venezuela dışındaki ülkelerin hepsi Orta Doğu bölgesinde yer almaktadır ve dünya petrol rezervinde en büyük paya sahip ülkeler olarak gözükmektedirler. Dünya enerji tüketiminde önemli paya sahip olan ABD, Çin, Hindistan gibi ülkeler ise petrol rezervi bakımından dünyadaki payları oldukça düşüktür. ABD \%2,2, Çin \%1,1, Hindistan ise $\% 0,7^{\prime}$ lik paya sahiptir. Avrupa Birliği'nin dünya toplam petrol rezervindeki oranı ise $\% 0,5^{\prime}$ dir.

\section{Dünya Petrol Üretimi Ve Orta Doğu}

Dünya petrol rezervinde ilk sırada yer alan Orta Doğu bölgesi, petrol üretiminde de dünyada ilk sırada yer almaktadır.

Tablo 3: Bölgelere Göre Petrol Üretimi(2010-\%)

\begin{tabular}{lr}
\hline ORTA DOĞU & 30,3 \\
AVRUPA-AVRASYA & 21,8 \\
K. AMERIKA & 16,6 \\
AFRIKA & 12,2 \\
ASYA PASIFIK & 10,2 \\
G. ve ORTA AMERIKA & 8,9 \\
\hline TOPLAM & $\mathbf{1 0 0}$ \\
\hline
\end{tabular}

Kaynak: (BP,2011: 8)

Orta Doğu bölgesi \%30,3'lük payla petrol üretiminde dünyada ilk sırada yer almaktadır. Avrupa ve Avrasya bölgesi \%21,8, Kuzey Amerika $\% 16,6$, Afrika \%12,2, Asya Pasifik bölgesi \%10,2, Güney ve Orta Amerika bölgesi ise $\% 8,9^{\prime}$ luk paya sahiptir.

Tablo 4:Petrol Üretiminde En Büyük Paya Sahip 15 Ülke(2010-\%)

\begin{tabular}{lrll}
\hline 1) RUSYA FED. & 12,9 & 8)BAE & 3,3 \\
2) SUUDİ ARABISTAN & 12 & 9) VENEZUELA & 3,2 \\
3) ABD & 8,7 & 10) IRAK & 3,1 \\
4) İRAN & 5,2 & 11) KUVEYT & 3,1 \\
5) ÇIN & 5,2 & 12) NiJERYA & 2,9 \\
6) KANADA & 4,2 & 13) BREZILYA & 2,7 \\
K) MEKSIKA & 3,7 & 14) NORVEÇ & 2,5 \\
$\mathbf{a}$ & & 15) AB & 2,4 \\
\hline $\mathbf{y}$ & & &
\end{tabular}

Kaynak: (BP,2011: 8) 
$\mathrm{Bu}$ durum ülkeler bazında değerlendirildiğinde ilk sırada Rusya Federasyonu \%12,9 ile ilk sirada yer almaktadır. Suudi Arabistan ise \%12 ile ikinci sırada yer bulunmaktadır. ABD ise petrol üretiminde $\% 8,7$ ile üçüncü sıradadır. Petrol üretiminde Orta Doğu ülkelerine bakıldığında Suudi Arabistan, İran, BAE, Irak ve Kuveyt gibi Orta Doğu ülkelerinin dünyada ilk 11 sırada yer aldığını görülmektedir. Suudi Arabistan \%12 ile 2. Sırada, İran $\% 5,2$ ile 4.sirada, BAE \%3,3 ile 8.sirada, Irak ve Kuveyt ise \%3,1'lik paylarıyla 10 ve 11. Sırada yer almaktadır. Ayrıca 2009 yılı verilerine göre Orta Doğu'da üretilen enerji kaynakları arasında petrol \%51,2 ile bölgede en çok üretilen enerji kaynağı olmuştur. Petrolü \%48,3 ile Doğalgaz izlemiştir (IEA,2010). Bu verilere göre değerlendirildiğinde Ortadoğu'da enerji üretiminin neredeyse tamamının petrol ve doğalgaz üzerine olduğu ortaya çıkmaktadır.

\section{Dünya Petrol Tüketimi Ve Orta Doğu}

Dünya petrol tüketiminde en önde olan bölge \%31'lik tüketim oranı ile Çin, Hindistan ve Japonya gibi ülkelerin yer aldığı Asya Pasifik bölgesidir. İkinci sırada ise \%26 ile ABD'nin sürüklediği Kuzey Amerika bölgesi gelmektedir.

\section{Şekil 4:Dünya Petrol Tüketimi Bölgelere Göre Dağılımı(2010-\%)}

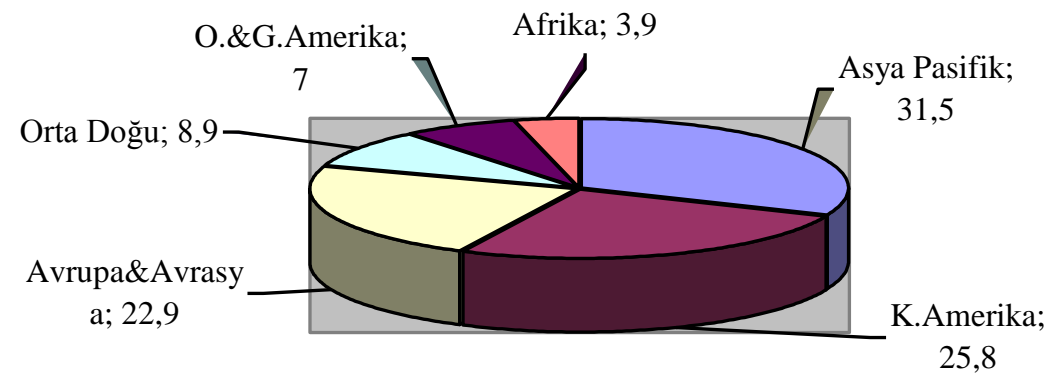

Kaynak: (BP,2011:9)

Şekil 4'te yer aldığı gibi Avrupa \& Avrasya bölgesi \%23 ile üçüncü en çok tüketim yapılan bölge olmuştur. En az petrol tüketimi yapılan bölge \%3 ile tahmin edileceği gibi Afrika'dır. Şekildeki önemli noktalardan biri ise Orta Doğu'nun durumudur. Petrol rezervinde ve üretiminde birinci sırada yer alan bu bölge, tüketim rakamlarında \%9 ile. 4 . en çok tüketim yapılan bölge olmuş ve sıralamada geride kalmıştır. Buradan yola çıkarak Orta Doğu'da üretilen petrollerin büyük kısmının ihraç edildiği sonucuna varılabilir. 
Ülke bazında tüketim oranları incelendiğinde en fazla tüketimin yapıldığı ülke ise $\mathrm{ABD}^{\prime}$ dir.

Tablo 5:Ülkelere Göre Dünya Petrol Tüketimi Sıralaması(2010-\%)

\begin{tabular}{lrlr}
\hline 1) ABD & 21,1 & 7) ALMANYA & 2,9 \\
2) Çİ & 10,6 & 8) BREZILYA & 2,9 \\
3) JAPONYA & 5 & 9) G. KORE & 2,6 \\
4) HINDISTAN & 3,9 & 10) KANADA & 2,5 \\
5) RUSYA FED. & 3,7 & 11) MEKSIKA & 2,2 \\
6) SUUDİ A. & 3,1 & 12) İRAN & 2,1 \\
& & TOPLAM & $\mathbf{6 2 , 6}$ \\
\hline
\end{tabular}

Kaynak: (BP,2011:9)

ABD petrol tüketiminde \%21,1'lik oranıla en fazla petrol tüketimi gerçekleştiren ülkedir. İkinci sırada \%10,6 ile Çin, üçüncü sırada ise \%5 ile Japonya yer almıştır. Petrol tüketiminde ilk onda yer alan diğer ülkeler ise \%3,9 ile Hindistan, \%3,7 ile Rusya, \%3,1 ile Suudi Arabistan, \%2,9 ile Almanya ve Brezilya, \%2,6 ile Güney Kore ve \%2,5 ile Kanada'dır. Petrol tüketiminde Orta Doğu ülkelerine bakıldığında ilk 10'da sadece Suudi Arabistan \%3,1 ile yer almaktadır. Diğer bir Orta Doğu ülkesi İran ise listede $\% 2,1$ ile 12.sıradadır. Petrol üretimi ve rezervinde liste başı olan Orta Doğu ülkelerinin çoğu tüketim sıralamasında gerilerde yer almış, sadece İran ve Suudi Arabistan tüketimde belirli bir paya sahip olabilmişlerdir. Petrol rezervinde gerilerde kalan $\mathrm{AB}$ ülkelerinin toplam petrol tüketimindeki oranı ise \%16,4'dür (BP,2011). $\mathrm{AB}$ bu oranyla Toplam tüketimde $\mathrm{ABD}^{\prime}$ nin arkasında ikinci sırada yer almaktadır. $A B^{\prime}$ de bu özelliğiyle petrol üretimine sahip ülkeler için önemli bir alıcı durumundadır.

\section{Dünya Doğalgaz Rezervleri Ve Orta Doğu}

Enerji konusunda diğer öne çıkan başlık ise doğalgazdır. Dünya enerji tüketiminde petrol ve kömürden sonra en fazla kullanılan enerji türü olmakla beraber giderek daha yüksek bir kullanım oranına erişileceği tahmin edilmektedir. 2009 yılı toplam enerji üretiminin \%21'i doğalgazdan sağlanmıştır (İEA,2010). Bölgeler olarak doğalgaz rezervleri değerlendirildiğinde Orta Doğu'nun 2010 yılı verilerine göre, ispatlanmış doğalgaz rezervinde dünyada birinci sırada yer alması dikkat çekicidir. 


\section{Şekil 5:Bölgelere Göre Dünya Doğalgaz Rezervi(2010-\%)}

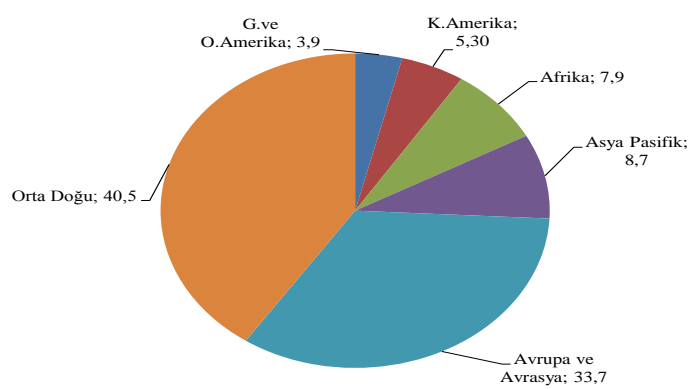

Kaynak:( TPAO,2010:9)

2010 yılı verilerine göre Ortadoğu bölgesi doğalgaz rezervinde $\% 40,5$ ile ilk sırada yer alırken, Avrupa ve Avrasya bölgesi \%33,7 ile ikinci sırada yer almaktadır. Asya Pasifik bölgesi \%8,7, Afrika \%7,9, Kuzey Amerika \%5,3 ve son olarak Güney ve Orta Amerika \%3,9'luk oranla sıralanmaktadır. Ülkeler bazında doğalgaz rezervlerine bakıldığında ise Rusya'nın dünyadaki doğalgaz rezervlerinde en büyük paya sahip ülke olduğu görülmektedir.

Tablo 6: Doğalgaz Rezervi Ülkelere Göre Dağılımı(2010-\%)

\begin{tabular}{lr}
\hline 1) RUSYA FED. & 24 \\
2) İRAN & 15,8 \\
3) KATAR & 13,5 \\
4) SUUDİARABISTTAN & 4,3 \\
5) TÜRKMENISTAN & 4,3 \\
6) ABD & 4,1 \\
7) BAE & 3,2 \\
8) VENEZUELA & 2,9 \\
9) NIJERYA & 2,8 \\
10) TUNUS & 2,4 \\
\hline TOPLAM & 77,3 \\
\hline
\end{tabular}

Kaynak: (BP,2011:20) 
Doğalgaz rezervi sıralamasında Rusya'dan sonra en büyük pay \%16 ile İran'dadır. Üçüncü sırada ise \%14 ile Katar gelmektedir. Bu ülkeleri Suudi Arabistan, Türkmenistan, ABD, BAE, Venezuela, Nijerya, Tunus ve Irak gibi ülkeler izlemektedir. $A B^{\prime}$ nin sahip olduğu doğalgaz rezervinin dünyaya oranı ise sadece \%1,3' dür $(B P, 2011)$. Orta Doğu ülkelerinin doğalgaz rezerv dağılımındaki paylarına bakacak olursak bu bölgedeki İran \%16 ile 2.sırada, Katar \%14 ile 3.sırada, Suudi Arabistan \%4 ile 4.sırada, BAE $\% 3,2$ ile 7. sırada, Irak ise \%1,7 oranındaki rezerviyle dünyada 11.sırada yer almaktadır. Doğalgaz rezervi bakımından en zengin 11 ülke arasında 5 Orta Doğu ülkesi yer almaktadır.

\section{Dünya Doğalgaz Üretimi Ve Orta Doğu}

Dünya doğalgaz üretiminde bölgesel veriler incelendiğinde en büyük payın Rusya gibi önemli bir üreticinin bulunduğu Avrupa \& Avrasya bölgesine ait olduğu görülmektedir.

\section{Şekil 6: Bölgelere Göre Doğalgaz Üretimi (2010-\%)}

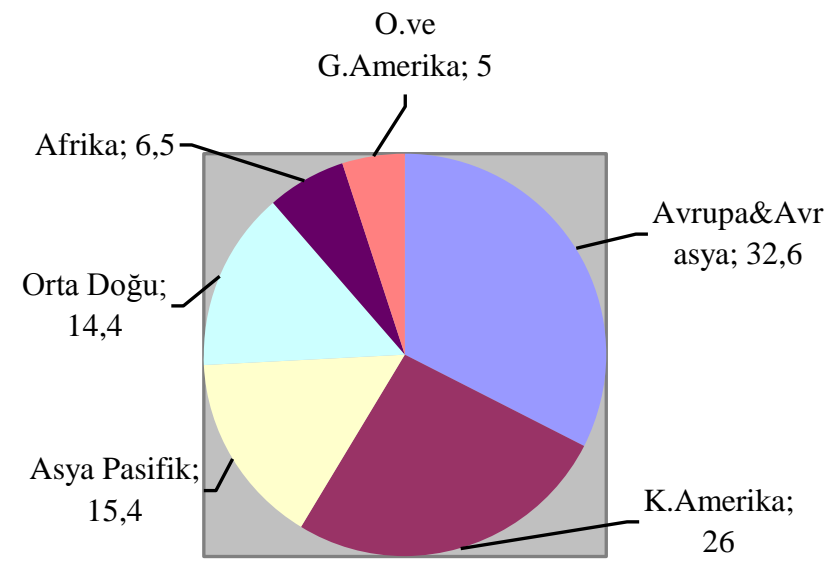

Kaynak: (BP,2011: 24)

Bu bölgenin \%33'luk oranını Kuzey Amerika bölgesi \%26 ile izlemektedir. Üçüncü sırada ise Asya Pasifik bölgesi \%15 ile yer almaktadır. Orta Doğu bölgesi ise dünya doğalgaz üretiminde \%14'lük paya sahiptir. Dünya doğalgaz üretiminde ülkelerin paylarına bakıldığında Rusya ve ABD'nin toplam payı dünyadaki üretimin üçte birinden fazlasına eşit olmaktadır. 
Tablo 7: Dünya Doğalgaz Üretimi Ülkelere Göre Dağılımı(2010-\%)

\begin{tabular}{lrlr}
\hline 1) ABD & 19,3 & 7) Çi் & 3 \\
2) RUSYA F. & 18,4 & 8) SUUDİ A. & 2,6 \\
3) KANADA & 5 & 9) ENDONOZYA & 2,6 \\
4) İRAN & 4,3 & 10) CEZAYİ & 2,5 \\
5) KATAR & 3,6 & TOLAM & 64,6 \\
6) NORVEÇ & 3,3 & & \\
\hline
\end{tabular}

Kaynak: (BP,2011:24)

ABD \%19,3 ile ilk sırada, Rusya ise \%18,4 ile doğalgaz üretimiyle ikinci sırada yer almaktadır. Doğalgaz rezervinde oldukça fakir olan AB ülkelerinin doğalgaz üretimindeki payı ise 2010 itibariyle \%5,5 olmuştur $(\mathrm{BP}, 2011)$. Orta Doğu ülkelerinin doğalgaz üretimi paylarına bakıldığında İran \%4,3'lük payı ile dünyada 4.sırada yer almaktadır. Bir diğer Orta Doğu ülkesi Katar ise $\% 3,6^{\prime}$ lik payı ile 5.sırada yer almaktadır. Petrol üretiminde dünyada ikinci sırada yer alan bir diğer Orta Doğu ülkesi olan Suudi Arabistan doğalgaz üretimi sıralamasında ise \%2,6 ile 8.sırada yer almaktadır. 2010 verilerine göre doğalgaz üretimi bakımından en zengin 10 ülke arasında 3 Orta Doğu ülkesi yer almaktadır.

\section{Dünya Doğalgaz Tüketimi Ve Orta Doğu}

Yakın dönemde ülkelerin ekonomik gelişmesine bağlı olarak, enerji talebinde artışlar yaşanmış ve birincil enerji tüketim miktarlarında giderek daha yüksek noktalara erişilmeye başlanmıştır. Dünya birincil enerji arzını kaynaklara göre incelediğimizde ise doğalgazın öneminin gittikçe artacağ görülmektedir. 2010 yılında, enerji arzında petrolün gerisinde kalan doğalgazın 2035 yılına gelindiğinde petrol arzını geçmesi beklenmektedir. Bu tablo, enerji kaynakları arasında doğalgazın öneminin daha da artacağını gösteren bir gelişmedir (DEKTMK, 2012: 2).

Dünya Doğalgaz tüketimi bölgelere göre incelendiğinde üretimde ilk sırada yer alan Avrupa \& Avrasya bölgesinin tüketimde de ilk sırada yer aldığ̣ görülmektedir. Bölgenin ilk sırada yer almasında $A B$ ülkeleri ve Rusya gibi güçlerin bu bölgede yer alması gösterilebilir. Şekil $7^{\prime}$ de belirtildiği üzere ikinci sırada ise Kuzey Amerika bölgesi yer almaktadır. Kuşkusuz ki bu bölgenin tüketiminde büyük oranını ABD çekmektedir. Doğalgaz tüketiminde üçüncü sırada yer alan bölge ise Asya Pasifik bölgesidir. Bu bölgede yer alan ve enerji ihtiyacı giderek artan Çin, Japonya ve Hindistan gibi ülkeler açısından bölgenin tüketiminin çok olmasının sebebi daha iyi anlaşılabilir. 


\section{Şekil 7: Bölgelere Göre Doğalgaz Tüketimi(2010-\%)}

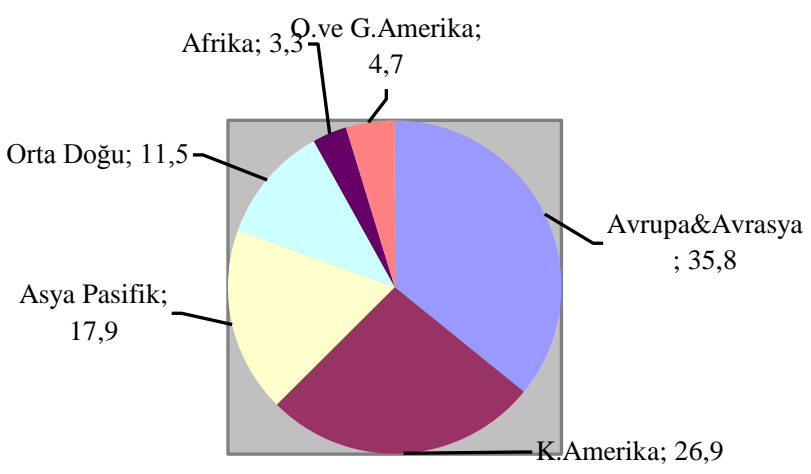

Kaynak: (BP,2011:25)

Doğalgaz tüketiminde Orta Doğu ise en fazla tüketim yapılan 4 . bölgedir. Üretim oranlarında \%14'lük paya sahip olan bölgenin tüketim oranlarındaki payı ise \%11 olmuştur. Orta Doğu'yu Orta ve Güney Amerika ile Afrika bölgeleri izlemektedir. Ülkeler bazında doğalgaz tüketim oranlarına bakıldığında ise 2010 yılı itibariyle ABD dünyada en fazla doğalgaz tüketimi yapan ülke durumundadır. $A B D$ tek başına $A B$ ülkelerinden daha fazla doğalgaz tüketimi yapmaktadır.

Tablo 8:Dünya Doğalgaz Tüketiminde ilk 10 Ülke Sıralaması(2010-\%)

\begin{tabular}{lrlr}
\hline 1) ABD & 21,7 & 7) B. KRALLIK & 3 \\
2) RUSYA F. & 13 & 8) SUUDI A. & 2,6 \\
3) İRAN & 4,3 & 9) ALMANYA & 2,6 \\
4) ÇİN & 3,4 & 10) İTALYA & 2,4 \\
5) JAPONYA & 3 & TOPLAM & 59,0 \\
6) KANADA & 3 & & \\
\hline
\end{tabular}

Kaynak: (BP,2011:25)

Dünya doğalgaz tüketiminde en büyük pay \%21,7 ile ABD'dir. ABD'yi \%13 ile Rusya takip etmektedir. Üçüncü sırada İran \%4'lük payıyla yer almaktadır. Asya Pasifik bölgesi ülkelerinden Çin \%3,4 ile 4.sırada, Japonya ise $\% 3$ ile 5.sırada yer almaktadır. Bu ülkeleri Kanada, Birleşik Krallık, Suudi Arabistan, Almanya ve İtalya takip etmektedir. AB ülkelerinin toplam tüketimdeki payı ise \%15,5'dir (BP,2011). Orta Doğu ülkelerine bakıldığında İran'ın dünya tüketiminde 3.sırada, Suudi Arabistan'ın ise 7.sırada yer aldığı görülmektedir. Sonuç olarak açıcça görülmektedir ki Orta Doğu bir enerji bölgesidir. Bunun yanında Orta Doğu bölgesinin hem 
doğalgaz hem de petrol üretim rakamları tüketim rakamlarından fazladır. Bu durum üretimin tüketimi karşılayamadığı ülkeler için Orta Doğu'yu en önemli ve stratejik enerji merkezi olarak algılamalarına yol açmaktadır. Tarihsel süreçte küresel güçler ülke sınırları dışında olan bölgelerde yer alan petrol ve doğalgaz kaynaklarını kontrol etmeye ve bu amaçla dış politikalarını oluşturmaya çalışmışlardır. Ortadoğu'ya artan ilginin ilk sırasında hegemon güç ABD gelmektedir. Özellikle Sovyetlerin dağılması ve Soğuk Savaşın sona ermesiyle tek kutuplu dünya düzeninde ABD bölgedeki gücünü sürdürmek amaciyla bölgeye yönelik yeni politikalar ortaya koymuştur.

Doğalgaz piyasası petrol ile kıyaslandığında, iki enerji kaynağının da belli üretim bölgelerinden tüketim bölgelerine doğru bir yön çizdiğini ifade etmekle birlikte, enerji ticaretinde farklı niteliklere sahip oldukları söylenebilir. Petrol ticaretinin yaklaşık 65'i deniz yoluyla, \%35'i ise boru hatları ile gerçekleşmektedir. Bu tablo doğalgazda ise oldukça farklıdır. Doğalgazın ise yaklaşık \%95'i boru hatlarıyla üretim sahalarından tüketici ülkelere ulaşmaktadır (Sevim, 2012: 4378-4391). Bu nedenle doğalgaz ticaretinde ve taşımacılığında boru hatları daha çok ön plana çıkmaktadır. Oluşan bu tabloya rağmen, coğrafi koşullar ve boru hatlarının maliyeti hesaplandığında bu enerji kaynağının üretim bölgelerinden tüketim alanlarına aktarımında sorunlar yaşanabilmektedir. Sıvılaştırılmış doğalgaz ticaretinin toplam doğalgaz taşımacılığındaki payının \%5 civarında olması nedeniyle doğalgaz, diğer enerji kaynaklarına oranla globalleşme noktasında sorunlar yaşayabilmektedir. Petrol pazarında gemi ve boru hatları yoluyla yapılan taşımacılığın daha dengeli bir seyir izlemesi, petrolün uluslararası arenada daha geçerli bir meta olmasına yol açarken, doğalgaz taşımacılığında boru hatlarının egemen konumu ve bu hatların yapımında etkili olan teknolojik boyut, ücretlendirme ve coğrafi koşullar, doğalgaz piyasasının kıtalar arası yayılımını olumsuz etkilemektedir. Dünyada en fazla doğalgaz rezervine sahip ülke durumunda olan ve doğalgaz üretiminde de ikinci sırada yer alan Rusya'nın dahi doğalgaz ticaretinin büyük kısmını coğrafi olarak kendisine yakın eski Sovyet ülkeleri ve Avrupa coğrafyasına gerçekleştirdiği düşünüldüğünde, doğalgaz piyasasının diğer enerji kaynaklarına oranla farklı noktaları ifade edilmiş olur.

Doğalgaz ticaretinde etkin yöntem olan boru hatları, aynı zamanda boru hatlarında yaşanan sıkıntılar, transit ülke geçişlerinde dönem dönem yaşanan kesintiler nedeniyle de tüketici ülkeler için hayati önem taşıyan gelişmeler arasında yer almaktadır. Özellikle doğalgaz piyasasında boru hatlarıyla etkili olmaya çalışan Rusya'nın Ukrayna ve Beyaz Rusya ile 
yaşadığı fiyat anlaşmazlıkları ve siyasi krizler neticesinde gaz akışında kesintiler yaşanması, gaz ihtiyacının büyük kısmını Rusya'dan karşılayan $\mathrm{AB}$ ülkelerinin gaz tedarikini sağlamada sorunlar yaşamasına neden olmuştur. Bu gelişmeler doğalgazda boru hattı taşımacılığının önündeki olumsuz gelişmeler olmakla birlikte sıvılaştırılmış doğalgazın kullanımının artmasına yol açacak girişimler, doğalgaz taşımacılığında daha dengeli bir seyrin yaşanmasına ve doğalgazın küresel enerji piyasasında rolünün daha da güçlenmesine neden olabilir. Son dönemde ABD'de bazı kamyon şirketlerinin petrol yerine sıvılaştırılmış doğalgaz ile çalışan araçlar üretmeye başlaması, petrolün yerini alması bakımından doğalgazı ön plana çıkarırken aynı zamanda gemi yoluyla sıvılaştııılmış doğalgaz taşımacılığında artışa geçebileceği yönündeki beklentileri arttırmaktadır. ABD'nin günlük petrol tüketiminin \%15'ini ağır ve orta ağırlıktaki araçlar tüketmektedir. Bu miktar, ABD'nin OPEC ülkelerinden ithal ettiği petrolün yaklaşık 3/4' üne eşittir. Bu araçların petrol kullanımından sıvılaştırılmış doğalgaz kullanımına geçmesi, dünyanın en fazla petrol tüketen ve dünya doğalgaz üretimi ile tüketiminde ilk sırada yer alan ABD'nin enerji tüketim profilinin doğalgaza kayması anlamına gelmektedir. Sıvılaştırılmış doğalgaz kullanımının Avrupa ve Kanada'da da giderek büyümesi beklenirken, bunun sonucunda dünya enerji piyasasında doğalgazın yükselişinin giderek daha küresel boyutta olması, olası gelişmeler arasında yer almaktadır ( Cardwell ve Krauss, 2013).

\section{Küresel Güçlerin Orta Doğu Politikaları}

\section{ABD'nin Orta Doğu Politikası}

Ortadoğu ABD için gerek ekonomik gerek siyasi yönden büyük öneme sahip bir bölgedir. Daha önce değinildiği gibi bölgede petrol ve doğalgaz gibi birincil enerji kaynakları yoğun oranda bulunmaktadır. Petrol söz konusu olduğunda bu durum ABD için özel önem teşkil etmektedir. ABD hem dünyanın en büyük petrol üreticileri arasında yer almakta, hem de dünyanın şu anda en çok petrol tüketen ülkesi konumundadır. Ülke dışında yer alan petrol bölgelerine yönelik politikalar, kendi çıkarlarını savunma girişimleri ve enerji hatlarının güvenliği üzerinde söz söyleme eylemleri ABD'nin enerji stratejilerinin çekirdeğini oluşturmaktadır.

İkinci Dünya Savaşı'nın ardından başlayan Soğuk Savaş döneminde batı dünyasının lideri durumunda yer alan $\mathrm{ABD}$, Ortadoğu'da etkin rol oynamaya, bu bölgede etkinliği Sovyetler Birliği'ne kaptırmamaya çalışmıştır. Bu bağlamda bir devletin kaybının diğer devletin kazancına eşit olacağı için uluslararası politikada sıfır toplamlı bir oyun dönemi yaşanmış, bölgede üstünlük kurma çabaları çatışma ortamına da zemin hazırlamıştır. 
Bu dönemde bölgede İran petrollerinin millileştirilmesi, Süveyş krizi, Arap İsrail savaşları, 1973 petrol krizi, İran Devrimi, İran-Irak Savaşı ve Camp David anlaşmaları gibi önemli gelişmeler yaşanmıştır. Soğuk Savaş sırasında bu bölge, kurulan ittifaklar, stratejik iletişim ve petrol ihracatı açısından bir ilgi odağı olmuş; Soğuk Savaş'ın bitmesiyle Ortadoğu, petrol üretimi ve ihracı konusunda global bir merkez olma özelliğini devam ettirmiştir (Norton,2000:31). Soğuk Savaşın sona ermesi ve Sovyetler'in dağılmasıyla birlikte Tek güç haline gelen $\mathrm{ABD}$, bölgeye yönelik yeni politikalar geliştirme çalışmaları içinde olmuştur. Sovyetler Birliği'nin dağılması bölgedeki dengeleri değiştirmiştir. Soğuk Savaş döneminde Sovyetlerle dostça ilişkiler içinde olan Arap ülkeleri, Sovyetlerin dağılmasıyla önemli bir desteğini kaybetmiş ve ABD'nin bölgeye girmesi kolaylaşmıştır. Düşman olarak nitelendirilen Sovyetler ve komünizmin çöküşü ile birlikte yeni düşmanlar ve tehditler arayışı içine girilmiştir. Bu bağlamda Huntington'un "Medeniyetler Çatışması" adlı eserinde bundan sonraki mücadele ortamının Hristiyan dünyası ile İslam dünyası arasında bir çatışma olacağı gibi düşünceler de ileri sürülmüştür. ABD'nin ise Soğuk Savaş sonrası için politikası yükselen İnsan Hakları, Demokrasi gibi kavramlar ile birlikte bu kavramların yayılmasına engel olarak görülen diktatör yönetimlere karşı mücadele etmek olmuştur (Huntington, 1997). Soğuk Savaş boyunca North Atlantic Treaty Organization (NATO) aracilı̆̆ıyla komünizme karşı mücadele eden ve ülkeleri bu yolla kendine bağlayan ABD Soğuk Savaşın sona ermesiyle dışa açılmak için yeni hedefler bulmak zorunda kalmıştır. ABD bu dönemde "Yeni Dünya Düzeni" kavramını ortaya çıkarmıştır. Demokrasi ve özgürlüğü tüm dünyaya taşımayı amaç edinen $A B D$, bir anlamda kendi düzenini tüm dünyaya empoze etme amacıyla yola çıkmıştır.

ABD'nin dış politikasında Soğuk Savaş sonrası bu gelişmeler yaşanırken Ortadoğu'ya yönelik önemli gelişmeler belirmiştir. “ABD dış politikası ile ABD petrol stratejileri ve çıkarları arasında, hedefler paralelinde ortak önemli ilişkiler mevcuttur. Yabancı petrol kaynaklarına ulaşabilme ve erişebilme, ABD için birçok kez ulusal güvenlik konusu olarak belirtilmiştir"(Alkin ve Atman, 2006:109). Hatta Ortadoğu'daki petrol kaynaklarının başıboş bırakılması ABD için bir felaket olarak belirtilmiştir. Büyük Ortadoğu Projesiyle ABD bölgeye yönelik amaçlarını gerçekleştirmeye çalışmışır. Bu proje kapsamında enerji kaynaklarının bölge ülkelerinde bulunduğu ve bu ülkelerin demokrasi bakımından zayıf, İnsan hakları konusunda gelişmemiş ve kişisel özgürlüklerin olmadığı ülkeler olarak vurgulanmıştır. Amaç Ortadoğu ülkelerine demokrasi ve insan haklarını getirmek olarak gözükse de asıl amaç kendi amacına hizmet edebilecek demokrasiyi, kültürel gelişimi sağlamak ve bölgede dost 
yönetimler kurmak olmuştur. Bölgedeki sorunlara karşllık tek süper güç durumundaki ABD, Birleşmiş Milletler (BM) ve NATO ile bölgeye sıcak temasta bulunmuştur. ABD'nin bu projeyi hayata geçirmesinde en önemli sebep bölgede bulunan enerji kaynaklarıdır. Bölge ülkelerinin birçoğunda tek adam egemenliği görülmekte ya da siyasi çalkantılar yaşanmaktadır. Ayrıca bölgede terör olaylarının yaşanması ve terör örgütlerinin bu bölgeden beslenmesi de önemli bir olgu olarak ortaya çıkmaktadır. ABD bölgedeki otoriter yönetimlere sahip, siyasi karışıklıklar yaşanan bu ülkelere enerji kaynaklarının kontrolünü bırakmamak amacıyla bu ülkelere yönelik kendi sözünü geçirebileceği ve bölgeye yayılmasına olanak sağlayacak yönetimleri destekleme ve bu tarz yönetimler oluşturmaya çalışmıştır. Tüm bu amaçlarının özünde ise ABD bazlı yönetimler oluşturmak ve ABD'nin hegemonyasını bölgede devam ettirmek yer almıştır. Jeopolitikçilerin belirttiği gibi Ortadoğu'ya egemen olan ülkenin dünyaya egemen olacağı düşüncesi, $A B D$ dış politikasında da etkin bir şekilde görülmüş ve önemsenen bir görüş olarak ön plana çıkmıştır. ABD'nin bölgedeki enerji kaynaklarına sahip olduğu takdirde bu bölgedeki enerji kaynaklarına ihtiyacı olan ülkelere karşı da üstünlük sağlayacağı aşikâr bir gerçektir. Irak'ın Kuveyt'i işgaline karşılık ABD'nin izlediği metot ve müdahale, bir anlamda ABD için Ortadoğu ve enerji kaynaklarının önemini bir kez daha ortaya koymuştur.

ABD, bölge ülkelerinde Batı yanlısı yönetimler kurma ve bölgede oluşabilecek siyasi istikrarsızlıkları kendi lehine çevirme amacı gütmektedir. $\mathrm{Bu}$ amacın oluşmasında en önemli noktalardan biri ise enerji güvenliğinin sağlanmasıdır. ABD açısından enerji güvenliği önem teşkil etmektedir. 1967 yılında Arap-İsrail Savaşı sonrası Süveyş Kanalının 8 yıl süreyle kapalı kalması, 1982-1988 yılları arasındaki Irak-İran Savaşında Hürmüz Boğazı çıkışlı petrol ticaretinin durma noktasına gelmesi gibi örnekler, Orta Doğu enerji güvenliğinin dönem dönem sıkıntılı boyutlara ulaşttğını göstermekte ve $A B D$ 'nin bölgeye yönelik enerji politikalarının ne yönde gelişeceğinin göstermektedir (Sevim, 2012: 4378-4391).

\section{Körfez Savaşı}

1.Körfez Savaşı yeni Dünya düzeninin harekete geçirildiği ilk olay olmuştur. Savaşa Irak'ın perspektifiyle bakıldığında Irak, Kuveyt'e kalıcı bir işgal sayesinde Suudi Arabistan'ın OPEC' deki etkinliğine sahip olacağı muazzam rezervlere dayanarak kırabilecektir. Böylece Körfez Ülkelerini kendi alt emperyalist sistemine alma gücüne kavuşacaktır (Parlar,2003:559). Ayrica Kuveyt'in petrolde ucuz fiyat stratejisi uygulaması Irak'ın zararına neden olmuştur. Fakat bu durum ABD'nin bölgedeki stratejisine zarar 
verecek çünkü $A B D$ kendi çıarları dışında hareket eden bir gücün bölgede aktif rol oynamasını istememiştir. "ABD, Irak'ın Kuveyt'i işgalini; dünya petrollerinin \% 20'sini ele geçirme, OPEC'te denetim sağlama, Orta Doğu'da egemen güç olma, İsrail'in varlığına tehdit ve nükleer güce sahip olma bağlamında değerlendirmiştir"(Parlar, 2003:559). Oysa Iran- Irak savaşında $A B D$ ve birçok Avrupa ülkesi Irak'ı desteklemiştir. Bu savaş sonunda İran'ın muhtemel bir tehdit olma durumu geciktirilmiş buna karşıllı öngörülmeyen olmuş ve Irak bölgesel bir güç olarak ön plana çıkmaya başlamıştır. Irak'ın Kuveyt'i işgali aynı zamanda Saddam Hüseyin'in Arap dünyasının lideri olma çabalarını bir göstergesidir. ABD'nin Irak'a desteği ise Kuveyt'i ilhak etmesiyle son bulmuş ve Irak, beklenmedik bir şekilde karşılarında ciddi bir tepki bulmuşlardır. Irak'ın Kuveyt'i işgali üzerine BM, Irak askerlerinin Kuveyt topraklarından çekilmesi yönünde karar alınmıştır. Lakin bu karar Saddam Hüseyin'in planlarında bir değişikliğe sebep olmamıştır. "Eğer Saddam Hüseyin Kuveyt'i almayı ve tutmayı başarsaydı, OPEC üretiminin $\% 20$ 'si, dünya petrol rezervlerinin de \% 20'sinin doğrudan kontrolünü ele geçirmiş olacak ve komşu ülkeleri sindirecek konuma gelecekti" (Yergin, 2011:723). Ancak güç dengelerinin Irak yönünde bozulması başta ABD olmak üzere Batılı küresel güçlerin ekonomik ve siyasi çıkarlarına ters düşmüştür. Kuveyt'in petrollerinin Irak'in eline geçmesine müsaade etmeyecek olan $\mathrm{ABD}, \mathrm{BM}$ desteği ile birlikte yaptığı eylemi meşrulaştırarak askeri müdahalede bulunmuştur.

Savaşın amacı her ne kadar Kuveyt'in bağımsızlı̆̆ını geri kazandırmak gibi görünse de yarattığı sonuçlarına bakıldığında Irak'ın askeri olarak yükselişi engellenmiş ve Saddam Hüseyin'in bölgedeki gücü bastırılmıştır. Irak'ta Saddam Hüseyin karşıtı ayaklanmalar yaşanmıştır. Ayrıca batı dünyası için olası petrol sevkiyatına zarar verebilecek bir tehdit ortadan kaldırılmıştır. Savaşın ardından ortaya çıkan bir diğer konu ise Ortadoğu'daki güvenlik sorunu olmuştur. Bölgede yakın dönemde yaşanan Iran-Irak savaşı ve üç yıl sonra yaşanan Körfez Savaşı, bölgedeki ülkelerin savunma alanında harcama yapmalarına neden olmuştur. Bu ülkelerin birçoğu petrol üreticisi ülkelerdir. Dikkat edilecek nokta ise Petrol fiyatlarına bağlı olarak değişen gelirlerinin bazen $\% 10$, bazen $\% 40^{\prime} 1 \mathrm{n}$ silahlanmaya ayıran bu ülkelerin önemli bir kısmı kurulduğu günden bu güne kadar herhangi bir uluslararası ya da bölgesel çatışmaya veya savaşa bile katılmamış olmasıdır (Ayhan,2009:335). Körfez Kriziyle yaşanan silahlanma yarışı ile birlikte silah şirketlerinin Ortadoğu'daki pazarları büyümüştür. 
Tablo 9:Körfez Savaşı Dönemi Orta Doğu Ülkelerinin Askeri Harcamaları(Milyar Dolar)

\begin{tabular}{|l|l|l|l|l|}
\hline ÜLKELER & $\mathbf{1 9 8 8}$ & $\mathbf{1 9 8 9}$ & $\mathbf{1 9 9 0}$ & $\mathbf{1 9 9 1}$ \\
\hline LÜBNAN & 278 & --- & 884 & 687 \\
\hline İRAN & 1776 & 2229 & 2415 & 2347 \\
\hline İSRAİL & 12659 & 10931 & 11219 & 14490 \\
\hline TÜRKİYE & 9918 & 11478 & 13865 & 14243 \\
\hline KUVEYT & 3361 & 4172 & 16098 & 20980 \\
\hline UMMAN & 2397 & 2409 & 2704 & 2240 \\
\hline SUUDI் A. & 19743 & 18657 & 23445 & 22358 \\
\hline
\end{tabular}

Kaynak: (SIPRI,2011)

Stockholm Uluslararası Barış Araştırma Enstitüsü verilerine göre Ortadoğu ülkelerinin Körfez Krizinin yaşanmaya başladığı dönemlerde özellikle Irak'a komşu ülkelerin askeri harcamalarında artış olduğu görülmektedir. Irak'ın işgalinin Kuveyt' ten sonra Suudi Arabistan'a olacağ endişesi ile Suudi Arabistan'da bu yıllarda yüksek oranda askeri harcamalar yapılmıştır. Suudi Arabistan'ın askeri harcamaları 1990 yılı itibariyle 23 milyar doları aşmıştır. Kuveyt'in askeri harcamaları ise 1990 yılında bir önceki yıla göre yaklaşık dört kat artması da krizin yarattığı sonuçlar içinde dikkat çekici bir noktadır.

Soğuk Savaş'ın sona ermesiyle silahlanmaya yapılan harcamanın azalması beklenen günlerde yaşanan Körfez Krizi, bölge ülkelerinin silah harcamalarında artışa neden olmuştur. Ayrıca dikkat çekici bir diğer husus silah satış anlaşmalarında ABD şirketlerinin bölgedeki etkisidir. "1988 yılında gelişmiş ülkelerle yapılan silah satış anlaşmalarında ABD'nin payı \% 16,5 iken, Körfez Krizi sonrası Orta Doğu ülkelerinden gelen siparişlerin etkisiyle bu oran 1990'lı yıllarda aşamalı bir şekilde \% 55'e yükselmiştir"(Ayhan,2009:338). Açıktır ki Körfez savaşı sonrası ABD, Ortadoğu'da en etkili güç haline gelmiştir. Bununla birlikte kurmak istediği düzene karşı çıkanlara güç uygulayacağını açık bir şekilde ortaya koymuştur. Ortadoğu artık ABD'nin çıkarlarına göre düzenleyeceği bir yapıya kavuşmuştur. Arap ülkeleri cephesinden bakılacak olursa, Yom Kippur Savaşı ve sonrasında uygulanan petrol ambargosu ile Arap ülkeleri arasında oluşturulan dayanışma ve birlik, Irak'ın başka bir Arap ülkesi Kuveyt'e saldırması ve bunun sonucunda Irak'a karşı oluşturulan koalisyon güçlerinde Arap ülkelerinin de yer almasıyla zarar görmüştür. Bu durum 
$A B D$ ve İsrail'in bölge ülkeleriyle yakınlaşmalarına şüphesiz avantaj sağlamıştır.

\section{Eylül Sonrasi ABD’nin Ortadoğu Politikası}

11 Eylül 2001 günü İkiz kulelere yapılan saldırılar tüm dünyada şok etkisi yaratmakla kalmamış aynı zamanda tüm dünyanın terör algısının da değişmesine yol açmıştır. 11 Eylül'ün ardından ABD, Soğuk Savaş sonrası aradığ1 düşmanı, çıkarları için en büyük tehdidi bulmuştur; bu tehdit terörden başka bir şey değildir. İkiz Kulelere yapılan saldırıların ardından ABD yönetimi dış politikasını terörizmle mücadele başlı̆̆ı altında yürütmeye başlamıştır. Terörist gruplar ve terörizme destek veren ülkeler ABD'nin yeni hedefleri olmuştur. Saldırıların arkasında ise El Kaide terör örgütünün olduğu bildirilmiştir. Başkan George W. Bush tarafından 2002 yılında Bush Doktrini olarak ta anılan Ulusal Güvenlik Stratejisi açıklanmıştır. Bu doktrine göre "Soğuk Savaş sonrası tehdit ve güvenlik kavramlarını yeniden tanımlayan Amerikan yönetimi, kendi güvenliğine ya da ulusal çıkarlarına bir saldırı ya da tehdit oluştuğuna dair şüpheler edinirse, bu hedeflere yönelik önleyici saldırılarda bulunacaktır" (Ayhan,2007:358). ABD'nin yeni stratejisi içerisinde Ortadoğu bir anlamda hedef bölgesi haline gelmiştir. Ortadoğu'da İslami kaynaklı terör örgütlerinin varlığ 1 ve bölgedeki bazı ülkelerin terör eylemlerine göz yumması ABD için kendi varlığına ve çıkarlarına karşı yapılmış bir hareket olarak görmesine neden olmuştur. Bu saldırı aynı zamanda Bölgedeki hareket alanını arttırmak isteyen ABD için önemli bir fırsat olmuştur denilebilir.

11 Eylül sonrası Hristiyan Dünyası ile Müslüman dünyası arasındaki oluşan gergin ortam ise dikkat çekici bir boyuta ulaşmış ve radikal İslam $\mathrm{ABD}$ için bir tehdit haline gelmiştir. ABD için tehdit ve düşmanlar artık belli olmuş sıra düşmanlara karşı müdahaleye gelmiştir. “ABD teröre karşı küresel savaş ilan ederek, bir taraftan El Kaide'ye yataklık ettiği, teröristlere eğitim alanı olarak hizmet ettiği gibi gerekçelerle, bölgedeki $\mathrm{ABD}$ şirketleri için gerekli olan istikrarı Afganistan'a getireceği beklentisi ile 1990'larda desteklediği Taliban rejimini Aralık 2001'de devirmiştir" (Bal;2008:104-105).

\section{Körfez Savaşı}

11 Eylül saldırıları sonrasında güvenlik stratejisini değiştiren ABD aynı zamanda kendisini tehdit edebilecek durumlar oluştuğu takdirde müdahalede bulunabileceğini açıklamıştı. Hatta ABD yönetimi bu hedefleri açık bir şekilde dile getirmişti. “ABD Başkanı George Bush, 29 Ocak 2002' de 
ulusa seslenişte "Şer Ekseni" tanımlamasıyla İran, Irak ve Kuzey Kore'yi de Amerikan güvenliğini tehdit eden ülkeler olduğunu ileri sürmüştü" (Ayhan,2009: 357). ABD açısından bu üç ülkenin bir diğer ortak özelliği ise kitle imha silahı üretmeleridir. Şimdiki bilinmeyen, Afganistan'dan sonra sırada bu üç ülkeden hangisinin olacağıdır. Başkan Bush döneminde Irak ve Saddam yönetimi, ABD için değiştirilmesi gereken yönetimlerden biri olarak gözükmekteydi. ABD yönetimi söylemlerinde demokrasi adına rejim değişikliklerinin yaşanması gerekliliğini vurgulamaktaydı. 11 Eylül sonrası caydırıcılıktan çok, güç kullanmaya daha hevesli görünen ABD, 2003 yılının Mart ayında Irak' 1 işgal etmiştir.

ABD'nin Irak işgali sadece Saddam Hüseyin'den kurtulma ya da kitle imha silahlarının ele geçirilmesi operasyonu değil aynı zamanda yeni bir düzen oluşturma operasyonu olmuştur. " Temel hedef, Orta Doğu ve Orta Doğu'daki enerji kaynakları üzerinde bölge dışı rakip bir gücün bölgeye girişini engellemek ve bölge içinden $A B D^{\prime}$ ye ve $A B D$ 'nin bölgedeki müttefiki İsrail'e meydan okuyacak bir devletin varlığını engellemek olarak tanımlanabilir" (Ahmetbeyoğlu vd., 2003: 153). Orta Doğu petrollerinin dünyadaki toplam petrol kaynakların \% 60-65'ine tekabül ettiği düşünüldüğünde bölgede etkin olmanın aynı zamanda büyük ekonomik kazançlar getireceği açıtır. Bölgede kendine dost yönetimler oluşturmak ABD için önemli bir strateji aracı olmuştur. Müdahale bir anlamda enerji güvenliğini sağlama amacı da gütmüştür. $\mathrm{ABD}$ bu müdahale ile rakip küresel güçlere karşı bir hamle de yapmış olmaktadır. ABD'nin tutumu Rusya ve Fransa gibi bölge ülkeleriyle petrol anlaşmaları yaparak bölgeye giren rakip güçleri bertaraf etmek için çevreleme teorisine benzer bir düzen oluşturarak bölgeyi kendisi için kontrol etmektir (Üşümezsoy ve Şen, 2003: 162). Zira Çin, Rusya ve AB ülkelerinin enerji politikaları ABD çıkarlarını etkilemektedir.

Bu bakımdan dünyanın en önemli enerji kaynağı olan Orta Doğu üzerindeki rekabet de hızla artmaktadır. Benzer şekilde, Hazar Petrolleri, Kafkasya ve Karadeniz üzerinde de bir rekabet yaşanmaktadır. Bu durum Orta Doğu'nun önemini daha da arttırmaktadır. ABD hegemonyasının 21. yüzyılda da sürdürülebilirliği bölge enerji kaynaklarının kontrolüne bağlıdır (Akbaş, 2011: 1-18). ABD'nin enerji kaynaklarına erişimi ve bölgedeki hegemonyasını devam ettirme amacına yönelik yaptığı Irak müdahalesi Çin ve Rusya gibi güçler tarafından eleştirilse de İsrail ve İngiltere tarafından desteklenmiştir. Bu destek ise son derece normal karşılanmalıdır. İngiltere ile bölgedeki çıkarlarının ortak olması İngiltere ile ABD'yi bölgede beraber hareket etmeye sevk etmiştir. İsrail'in varlığının korunması ise ABD'nin Büyük Orta Doğu Projesinde yer alan başlıklardan biri olmuştur. 11 Eylül 
saldırıları bir anlamda ABD'nin bölge ülkelerine müdahalesini kolaylaştırmış ve kendisine göre haklı bir sebep yaratmış bir anlamda askeri müdahalelerini yasallaştırma imkânı bulmuştur. 11 Eylül sonrası Afganistan ve Irak müdahaleleri ile bölgedeki gücünü göstermiş, bölgedeki petrol kaynaklarını kendi kontrolüne almıştır.

\section{İran İle İlişkiler}

İran ABD ilişkileri incelendiğinde iki ülke arasındaki gelişmeler İran petrolleri nedeniyle yakın seyir izlemiştir. İran petrolünün Mussadık yönetimi tarafından millileştirilme girişimi CIA destekli darbeyle Şah yönetiminin gelmesine neden olmuştur. Şah döneminde ABD ile dostça ilişkiler yaşanmıştır. Ancak 1979 İran İslam Devrimi ile birlikte ABD bölgedeki önemli bir müttefikini kaybetmiştir. 1979'dan günümüze kadar İran ABD ilişkilerinde gerginlik hâkim olmuş ve ABD İran' 1 "Büyük Şeytan" olarak adlandırmıştır. Son dönemde İran'ın nükleer enerji programı ABD tarafından tepkiyle takip edilmiş ve ABD yönetiminin uluslararası kamuoyundaki çalışmaları ile birlikte BM tarafından ambargo uygulanmaya başlanmıştır. Günümüzde İran Orta Doğu'da ABD karşıtı yönetimlerin başında gelmektedir. İran dünyada kanıtlanmış petrol rezervlerinin \% $10^{\prime}$ una ve kanıtlanmış doğalgaz rezervlerinin \% 16'sına sahiptir $(B P, 2011)$.

İran'ın doğalgaz ve petrol kaynaklarının bulunmasının yanı sıra jeostratejik önemi de göz ardı edilmemelidir. " İran stratejik olarak kanıtlanmış dünya petrol rezervlerinin en az \% 50'sini oluşturan Suudi Arabistan, Kuveyt, Irak, Birleşik Arap Emirlikleri (BAE)' nin petrol sahalarını tehdit edebilecek bir konumda olmasının ötesinde dünya petrol tüketiminin \% 40'ının karşılandığı Hürmüz Boğazı'nı da denetleyen bir jeostratejik konuma sahiptir" (Ayhan, 2009:419). İran'ın doğalgaz ve petrol rezervleri, Batı karşıtı yönetimi ve bölgesel güç olarak giderek güçlenmesi ABD açısından tehdit olarak algılanmasına neden olmaktadır. Ayrıca İan'dan petrol ithal eden ülkeler arasında Çin ilk sırada yer almaktadır. ABD'nin 21. yüzyıldaki en büyük rakibi olarak görülen Çin'in petrol ihtiyacını İran'dan karşılaması da ABD için oldukça önemli bir sorun olarak algilanmaktadır. ABD'nin, rakibini besleyen İran bir anlamda ABD'nin baş hedeflerinden biri durumundadır. İran'dan petrol ithal eden ülkeler Çin'in ardından AB ülkeleri, Japonya, Hindistan, Güney Kore ve Türkiye olarak siralanmaktadır. 


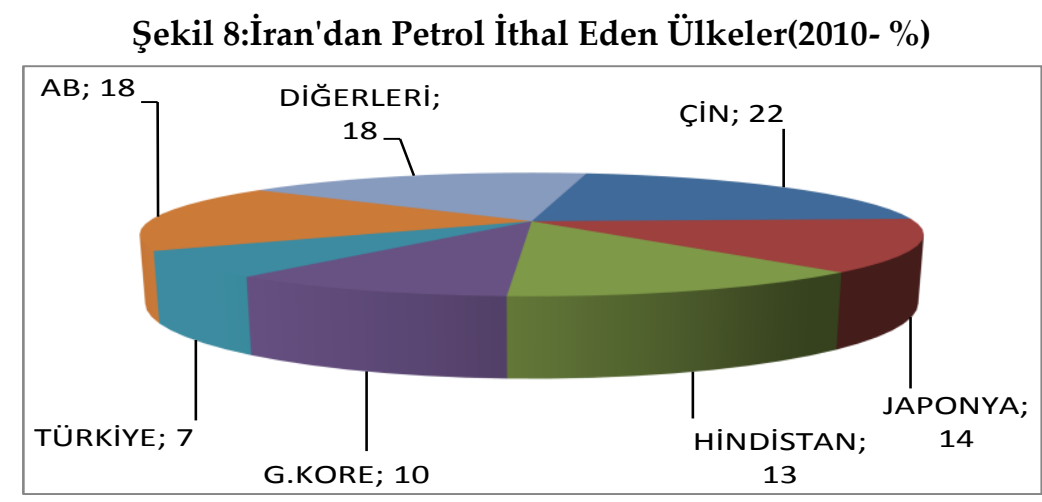

Kaynak: (İEA,2011)

İran'ın petrol ihracatının büyük kısmının Uzak Doğu'ya olması dikkat çekici bir noktadır. Son dönemde İran'a karşı ABD tarafından yaptırım kararı alınmış, bu karar en çok İran'dan petrol ithal eden ülkeleri zor durumda bırakmıştır. Bu kapsamda Türkiye'de de sıkıntılar yaşamış İran'dan alınan petrolde \% 20 kesintiye gidileceği belirtilmiştir ve bu ihtiyacın Libya'dan petrol alımıyla kapatılmaya çalışılacağı dile getirilmiştir. İran' a uygulanan ambargodan dolayı birçok ülke için Libya çözüm yolu olacaktır. NATO operasyonu sonrası Libya petrollerinin Amerikan ve Fransız şirketlerinin elinde olması da bu ambargonun en çok kimi fayda sağlayacağı ortaya sermektedir. İran'dan petrol alımını düşüren 11 ülke ise bu yaptırımdan muaf tutulmuşlardır. Bu ülkeler içinde on $A B$ ülkesi ve Japonya yer almaktadır.

\section{Rusya'nın Ortadoğu Politikası}

Soğuk Savaş döneminde Orta Doğu'yla yakından ilgilenen ve ABD ile bölgeye egemen olma yarışında olan Sovyetler Birliği'nin 1991'de dağılmasıyla birlikte kurulan Rusya Federasyonu ilk yıllarında bölgeye yönelik politikalar konusunda pasif kalmıştır. Bu dönemde siyasi ve ekonomik sorunlarla boğuşan Rusya 1999 yllında Putin'in iktidara gelmesiyle bölgeye yönelik özellikle enerji konusunda politikalar yürütmeye başlamıştır. Rusya zengin enerji kaynaklarına sahip olmakla birlikte önemli enerji hatları üzerinde yer almaktadır. 2010 verilerine göre kanıtlanmış doğalgaz rezervlerinde dünyada ilk sirada, üretiminde ise $\mathrm{ABD}^{\prime}$ nin ardından ikinci sırada yer almaktadır (TPAO,2010:10-11). Rusya'nın sahip olduğu diğer önemli enerji kaynağı ise petroldür. 2010 yılında dünyada kanıtlanmış petrolün \% 5,6'sına sahip olan Rusya aynı zamanda petrol 
üretiminin de \% 12,9'u gerçekleştirip Suudi Arabistan'1 geçmiş ve 2010 yılının en fazla petrol üretimi yapan ülkesi olmuştur (BP,2011:6-8).

Rusya'nın sahip olduğu enerji kaynakları ekonomisi için büyük önem arz etmektedir. Bunun bilincinde olan Rus yönetimi enerji güvenliği ile ilgili stratejiler belirlemiştir. "Ulusal petrol rezervlerinin, kaynaklarının ve deniz aşırı geçiş alanlarının güvenliğine yeni dönemde öncelik veren Rusya; 21 Nisan 2000'de Başkan Vladimir Putin tarafından onaylanan askeri doktrinde; enerji güvenliği ve Hazar Bölgesi kaynaklarını ulusal çıkar olarak belirtmiştir"(Alkin ve Atman,2006:179). ABD'nin Afganistan'a müdahalesine destek veren Rusya, ABD'nin İran ile yaşadığı nükleer program sebepli gerilimde ise dengeli bir tavır sergilemektedir. İran'a uygulanan yaptırıma Rusya'nın karşı çıkması ve son dönemlerde Suriye'de yaşanan karışıklıklarda $A B D$ ve Rusya arasındaki görüş farklılıklarının son dönemdeki başlıca konuları arasında olduğu söylenebilir. Rusya bölgede ekonomik ve kültürel işbirliği aracılığıyla bölge ülkeleriyle yakınlaşmak istemektedir. Rusya'nın İslam Konferansı Örgütü'ne gözlemci statüsünde üye olması da bölgeye olan ilgisini ortaya koymaktadır. Rusya'nın özellikle İran ile bölgede stratejik işbirliği içinde olduğu göz ardı edilmemelidir. Bu işbirliğindeki en önemli sebep ise $\mathrm{ABD}$ olmuştur. İki ülkenin de ABD'yi bölgede tehdit olarak algılaması İran ile Rusya'nın işbirliğini arttırmaktadır. Diğer yandan ABD'nin muhtemel bir İran saldırısı petrol fiyatlarının artışına neden olacak ve bu artış daha öncede OPEC krizlerinden faydalanan ve ekonomisini güçlendiren Rusya'ya yarayacaktır. “Rusya'nın İran politikası moda deyimiyle kazan kazan politikasına dönüşmüştür. Rusya İran'ı herhangi bir saldırıdan koruyabildiği sürece bölgede güçlü görünüp önemli bir ortak kazanacak; bunu engelleyemez ve istikrar bozulursa artan petrol fiyatları yine Rusya'nın ekonomisine yarayacaktır" (Tellal,2010:228). Sonuç olarak Rusya Federasyonu sahip olduğu enerji kaynaklarıyla birlikte sadece bölgede değil Dünya'da petrol ve doğalgaz fiyatlarını etkileyen küresel bir güçtür. Putin dönemiyle birlikte Orta Doğu'da daha etkin görünmek isteyen Rusya, bölgede küresel bir güç olmak için etkisini hissettirmek istemektedir. Zira Rusya ancak bu şekilde ABD'nin bölgede rahatça yayılmasını engelleyebilir. Bu amaçla bölge ülkeleriyle yapılacak ortaklıklar Rusya'nın ABD karşısındaki kozunu güçlendirebilir.

Rusya'nın enerji politikalarında önemli yer tutan noktalardan bir diğeri ise enerji güvenliğidir. Rus enerji kaynaklarının Batı ülkelerine ticaretinde kullanılan boru hatlarında özellikle transit ülke geçişlerinde yaşanan sorunlar, Rusya'nın alternatif enerji hatları oluşturmasına ve transit ülkeleri devre dışı bırakan projelerin altına imza atmasına neden olmaktadır. Bu 
noktada oluşturulan Kuzey Akım Doğalgaz Boru Hattı ${ }^{1}$ ve Baltık Petrol Boru Hattı'nın ikinci aşamas12, Rusya'nın transit ülkeler olmadan doğalgaz ve petrolünü Batıya aktarmasına olanak sağlamaktadır. Rusya'nın enerji tedarikinde güvenilir bir konuma gelmesi, OPEC ülkeleri başta olmak üzere önemli petrol ve doğalgaz üreticileri için olumsuz bir tablo oluşturmaktadır. Özellikle son dönemlerde Orta Doğu coğrafyasında yaşanan siyasi krizler ve bu krizlerin sonucunda enerji güvenliğinin dönem dönem tehlikeye girmesi, Orta Doğu ülkelerinin enerji piyasasındaki itibarı açısından önemli bir sorun teşkil etmektedir.

\section{Çin'in Enerji Bağımlılığı Ve Ortadoğu}

Büyüyen ekonomisi, Dünyanın 5'te birine tekabül eden nüfusu ve geniş coğrafyası ile Çin dünyanın önemli güçlerinden biridir. Çin'in büyüyen ekonomisine karşılık sahip olduğu enerji kaynakları yeterli olmamış ve 1993 yılından itibaren Çin petrol ithal eden ülkeler arasına girmiştir. Çin 2010 verilerine göre dünyadaki petrol rezervinin \% 1,1'ine sahip olmakla birlikte petrol üretiminin ise \% 5,2'sini gerçekleştirmektedir (BP,2011:6-8). Bununla birlikte 2010 yılında toplam petrol tüketiminde ABD'den sonra Çin \% 10,6 ile ikinci sırada yer almaktadır (BP,2011:9). Çin'in üretim ve tüketim rakamları arasındaki büyük uçurum ülkenin sınırları dışındaki petrol kaynaklarına olan ilgisini arttırmıştır.

\footnotetext{
${ }^{1}$ Kuzey Akım Boru Hattı, Rusya'nın doğalgazını transit ülkeler olmaksızın Avrupa pazarına sokmasına imkân vermiştir. Bu proje ile birlikte Rus doğalgazı Baltık Denizi altından Almanya'ya ulaşmaktadır. Polonya gibi transit ülkelerin devre dışı bırakılması ile Rusya, hem enerji piyasasında elini güçlendirmiş hem de enerji tedarikinde güvenilir bir ülke olma yolunda Batı nezdinde önemli itibar kazanmıştır (Nord-Stream, 2013).

${ }^{2}$ Baltık Petrol Boru Hattı'nın ikinci aşaması, yakın dönemde Beyaz Rusya ile Rusya arasında yaşanan siyasi kriz sonrası gündeme gelmiştir. Bu boru hattı ile Rusya, Beyaz Rusya'yı devre dışı bırakarak Batı ülkelerine tankerlerle petrol akışını gerçekleştirmektedir (Euractiv, 2009).
} 
Şekil 9:Çin Birincil Enerji Tüketimi Dağılımı (1990 - 2030-MTEP)

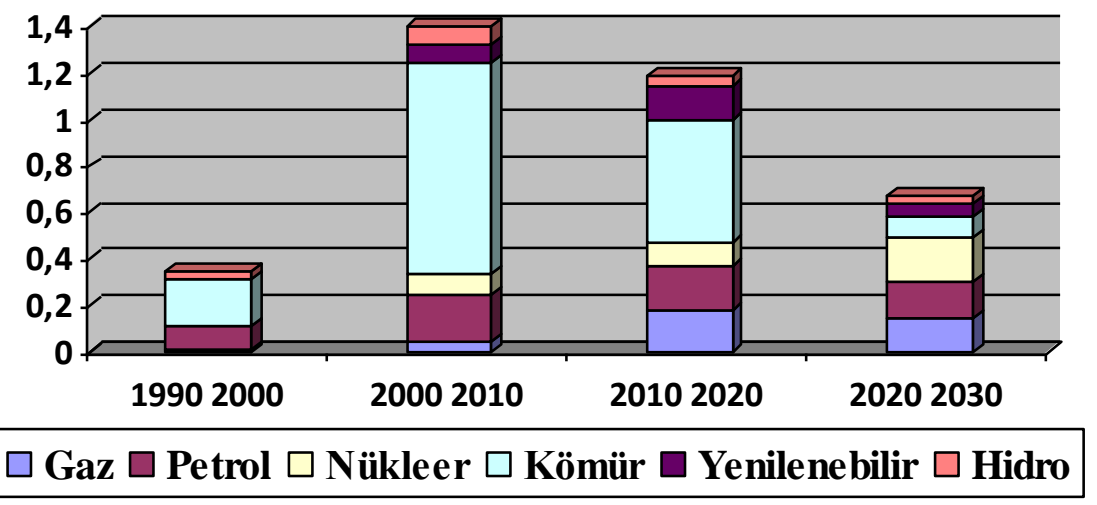

Kaynak: (BP, Energy Outlook 2030:50)

BP’nin yayınladığı rapora göre Çin'in enerji tüketimindeki artışın 2020 yılından sonra önemli ölçüde yavaşlaması beklenmektedir. Günümüzde Çin'in enerji tüketiminde en büyük payın kömürde olduğu görülmektedir. Kömürün tüketimdeki payı 2020 yılından itibaren düşüşe geçecek ve 2020-2030 döneminin tüketiminde büyük düşüş görülecektir. Doğalgaz tüketiminde ise 2010-2020 dönemi en tavan noktalar olacak ve 2020-2030 döneminde ufak düşüş olsa da Çin toplam tüketimindeki düşüş sebebiyle tüketimdeki payı artacaktır. Petrol tüketiminde ise 2010-2020 döneminde bir önceki döneme göre bir artış beklenmemekle beraber, üretimindeki düşüş sebebiyle tüketimdeki payı artacaktır. Çin'in petrol stratejisi birçok kaynaktan petrol elde etme ve bu kaynaklarını çeşitlendirme yönündedir. Buna rağmen Çin'in petrol ithalatında büyük pay Orta Doğu ülkelerine aittir. 2010 yllında 4,8 milyon varil petrol ithal eden Çin bu rakamın 2,2 milyon varilini, yani yaklaşık \%47'sini Orta Doğu ülkelerinden sağlamıştır . Ülke olarak petrol ithalatına bakıldığında Suudi Arabistan 893 bin varil ile ilk sırada gelmektedir . 2010 yılı Çin petrol ithalatı verilerine göre Orta Doğu ülkelerinden İran 426 bin varil ile 3. Sırada, Umman 317 bin varille 4.sırada, Irak 225 bin varille 7.sirada, Kuveyt ise 197 bin varille 8.sırada yer almaktadır. (EİA,2010).

Çin'in özellikle petrol ithalatında Orta Doğu ülkelerine bağımlılığı çok açık bir gerçektir. Bu sebeple Çin'in bölgedeki ülkelerle yakın ilişkiler geliştirmesi ilerideki yıllarda petrol sıkıntısı çekmesini engelleyebilir. Orta Doğu ülkelerinin genellikle İslam ülkelerinden oluşması Çin'in iç dinamiklerinde dikkatli bir tavır sergilemesini gerektirebilir. Çin'in Uygur bölgesinde yaşanan sorunlar Çin için ileride Orta Doğu ile ilişkilerde sorun 
yaratabilir. Uygur bölgesinin nüfusunun genellikle Müslüman olması ve Çin'in bölgeye yönelik sorunlara şiddet içerikli yaklaşması Çin'in ilerideki dönemde Orta Doğu ülkeleriyle sorunlar yaşamasına sebebiyet verebilir.

Çin'in Orta Doğu ülkeleriyle ilişkilerine bakıldığında “enerji güvenliği konusunda Suudi Arabistan, Sudan ve İran gibi ana petrol üreticisi ülkelerle açık bir şekilde ikili ilişkiler yürütmektedir " (Karaca,2004: 139). Çin için enerji güvenliği kritik bir konudur ve küresel olarak dünyayı da yakından ilgilendirmektedir. "Çin, sanayileşmesi için gerekli petrol girdilerini güvenlik altına almazsa ve yüksek maliyetli petrol giderleri üretim maliyetine yansırsa ihracata dayanan sanayileşmesi kısa bir gelecekte krize girerek içinden çıkılmayacak bir dünya ekonomik sistem krizine neden olabilir" ( Üşümezsoy ve Şen,2003: 174-175). Son dönemde Çin bölgede İran ile enerji politikalarında işbirliği yapmaktadır. ABD'nin yaptırım kararıyla birçok batılı ülke İran'dan petrol alımını kısmaya çalışmakta ancak Çin İran'la yeni anlaşmalar yapmaktadır. Çin, İran ham petrolünün \% 20'sini satın almaktadır (EİA,2010). Çin için İran önemli enerji kaynakları olan ve enerji ihtiyacını sağlayacağı kaynaklardan biridir. ABD'nin İran'a yapacağı muhtemel bir askeri operasyona karşı olan Çin yönetimi, Nükleer krizin çözümünün ancak müzakerelerle olabileceğini dile getirmiştir. Önümüzdeki yıllarda Çin'in ekonomisinin büyümesinin devam etmesi beklenmektedir. Ekonomisinin büyümesi ile enerji ihtiyacının artacağı düşünüldüğünde Çin'in petrol üreten ülkelere daha yakın olma ihtiyacı da artacaktır. Petrol ithalatının ilk sırasında Orta Doğu ülkeleri yer alan Çin'in bu bölgeye ilgisinin giderek artması ve diğer küresel aktörlerle bölgede rekabet içinde olması da kaçınılmaz bir durum olacaktır.

Çin açısından Hürmüz Boğazı, petrol ihtiyacını karşılama noktasında önemli bir merkezdir. Günümüzde Hürmüz Boğazından geçiş yapan petrol yükünün en büyük istikamet noktası günlük 6,8 milyon varil ile Asya-Pasifik bölgesidir. Hürmüz boğazının günlük toplam petrol hareketliliğinin 17 milyon varil civarında olduğunu düşürsek, boğazın petrol hareketliliğinin yaklaşı $\% 40^{\prime} 1$ Asya-Pasifik bölgesine gerçekleşmektedir. Hürmüz Boğazının petrol hareketliliğinde Çin'in payı ise yaklaşık 1,5 milyon varil civarındadır. Japonya, Avrupa ve ABD'nin ardından en fazla Hürmüz boğazından petrol tedarik eden ülke konumunda yer alan Çin açısından Hürmüz Boğazı, dolayısıyla İran'ın varlığı önem teşkil etmektedir (Sevim, 2012: 4378-4391). Bu kapsamda ABD'nin tek kutuplu dünya sistemine karşı ortak tavır içerisinde bulunan İran ve Çin, birbirileri için eşi bulunmaz bir stratejik ortaklığa sahiptir. Bu kapsamda Çin'in enerji talebini karşılamasında Orta Doğu coğrafyası ve Hürmüz Boğazı, jeostratejik öneme sahiptir. Bu kapsamda değerlendirirsek Çin için 
Orta Doğu, sadece enerji ihtiyacının karşılanması amacıyla önemli değil aynı zamanda jeostratejik noktaları açısından da hayati öneme sahip konumdadir.

\section{Avrupa Birliği'nin Orta Doğu Politikaları}

Avrupa Birliği'nin Orta Doğu'ya yönelik ilgisi uzun bir sürece dayanmakla birlikte bu ilgi ekonomik, jeostratejik ve kültürel sebepler olarak adlandırılabilir. Üç dinin kesişme noktası olması, coğrafi olarak Avrupa'ya yakınlığı ve doğal zenginliği ile Orta Doğu Avrupa için dikkat uyandıran bölgelerin başında gelmiştir. $A B^{\prime}$ nin enerji kaynaklarına bakıldığında dışa bağımlı yapısı ortaya çıkmaktadır. 2010 verilerine göre dünyadaki petrol üretiminin \% 2,4'ü $\mathrm{AB}$ ülkelerinde gerçekleşmiş, tüketim oranlarında ise bu rakam \% 16,4'e ulaşmıştır (BP,2011:8-9).

Gelişmiş $\mathrm{AB}$ ülkelerinin petrol tüketim rakamlarını kendi kendilerine karşılama imkânları yoktur. Petrolde dışa bağımlı olan $A B$, bu kaynakları en kolay, ucuz ve güvenilir yolları kullanarak Orta Doğu'dan sağlamaya çalışmaktadır. Aynı durum diğer bir enerji kaynağı doğalgazda da geçerlidir. Dünya doğalgaz üretiminde \% 5,5'lük bir paya sahip olan $A B$, tüketim oranlarında ise \% $15,5^{\prime}$ lik bir paya sahiptir. $A B$ doğalgaz tüketiminde $\% 62$, petrol tüketiminde ise $\% 84$ dışa bağımlı durumdadır (Eurostat, 2012). AB bu bağımlılığı azaltmak amaciyla 2030 yılı planlamalarında petrol tüketimini \% 40 oranında düşürmeyi amaçlamakta ve ihtiyacının bir kısmını da yenilenebilir enerjiden karşılamayı planlamaktadır. AB petrol ihtiyacını en çok Rusya'dan alarak kapatmaya çalışmaktadır. 2006 yılı verilerine göre, $A B^{\prime}$ nin petrol ithal ettiği ülkeler sırasıyla : \% 33 ile Rusya, \% 15,8 ile Norveç, \% 9,4 Libya, \% 9 Suudi Arabistan ve \% 6,4 ile İran'dır (Eurostat,2008).

Doğalgaz alımında da tablo değişmemekte ve $A B^{\prime}$ nin Rusya'ya ve Orta Doğu'ya bağımlılığı açıkça ortaya çıkmaktadır. AB'nin doğalgaz alımında da en büyük pay Rusya ve Norveç'in ardından Orta Doğu bölgesi olarak sıralanmaktadır. Gelişmiş ekonomileri ile birlikte artan enerji ihtiyacını karşılamada $A B$ ilerideki yıllarda daha büyük sıkıntılar yaşayabilir. Bu bağlamda $A B$ için özellikle zengin kaynaklara sahip Orta Doğu ve Rusya'nın önemi artarak devam edecektir. AB bu nedenle özellikle Orta Doğu'da yaşanacak değişimleri takip etmek zorundadır. Bu bölgede etkinliği sadece $\mathrm{ABD}^{\prime}$ ye bırakmak $\mathrm{AB}$ için oyunun dışında kalmak anlamına gelebilir. Özellikle İngiltere'nin ABD politikalarına her alanda destek vermesi, Almanya ve Fransa'nın ise birliğe katkı sağlamanın dışında kendi ekonomik çıkarları doğrultusunda bölgede hareket ettikleri 
düşünüldüğünde ilerleyen dönemde $A B^{\prime}$ nin enerji krizleri yaşaması olağan gelişmeler arasında yer alabilir.

$\mathrm{AB}^{\prime}$ nin petrol ve doğalgazda dışa bağımlılı̆̆ının yüksek olması nedeniyle yenilebilir enerji kaynaklarına doğru yönelme görülse de günümüz şartları itibariyle bunun tam anlamıyla gerçekleşmesi mümkün görülmemektedir. Özellikle petrol ve doğalgaz tedarikinde Rusya'ya olan bağımlılık, $\mathrm{AB}$ enerji politikalarında Rusya'ya alternatif projelerin ortaya çıkmasına neden olmaktadır. Bu kapsamda değerlendirirsek Rusya, petrol ve doğalgaz boru hatları ile $A B$ ülkelerini kendine bağımlı hale getirirken, $\mathrm{AB}$ ülkeleri ise özellikle enerji hatları konusunda alternatif projeleri destekleyerek enerji tedarikinde çeşitliliği sağlamaya çalışmaktadır. AB, Rusya'ya bağımlılığı azaltmak amacıyla Nabucco doğalgaz boru hattı projesini ortaya atmış ve bu proje ABD tarafından da desteklenmiştir. Bu desteğin arkasında ise Avrupa'nın enerji alanında Rusya'ya bağımlılığını azaltacağ 1 düşüncesine olan inanç yer almaktadır. Bu projeye karşılık Rusya, Güney Akım projesi ile Karadeniz altından boru hatlarıla Avrupa'ya gaz ulaşımının sağlanması amacında olmuştur. Özellikleri ve ulaşım noktalarına göre benzer nitelikleri taşıyan bu iki proje, bir anlamda enerji sektöründe siyasi mücadelelerin yaşandığı projeler olarak ön plana çıkmıştır.

Esas itibariyle enerji sektöründe dışa bağımlı durumda yer alan $A B$ açısından enerji güvenliği, hassas bir noktadır. Körfez Savaşları ve İran-ABD merkezli yaşanan krizler, Orta Doğu enerji kaynaklarına olan güvenin dönem dönem azalmasına neden olmaktadır. Orta Doğu'nun siyasi açıdan istikrarsız yapısı, $A B$ açısından enerji tedarikinde alternatif oluşumların denenmesine yol açmaktadır. Zengin doğal kaynaklara sahip Orta Doğu coğrafyasının $\mathrm{AB}$ enerji pazarındaki en büyük rakibi, Rusya olduğu kadar bu coğrafya ülkelerinin yaşadığı siyasi krizler ve istikrarsız siyasi yapıdır (Andersen, 2000).

\section{Sonuç}

Orta Doğu bölgesi zengin doğal kaynakları ile küresel güçlerin ilgi alanı olmuş ve bundan sonraki dönemde de bu ilgi artarak devam edecek gibi gözükmektedir . Hegemon güçler enerji ihtiyaçlarını bölgeden güvenilir ve ucuza sağlamak amacıyla bölgede etki alanı oluşturmak istemişlerdir. Bu amaçla bölgedeki yönetimlere bazen askeri bazen ekonomik bazen de siyasi etkilerde bulunmuşlardır. Soğuk Savaş dönemine Sovyetler Birliği ve ABD arasındaki bölgede etkin olma mücadelesi Sovyet'lerin dağılması ile ABD'nin bölgede avantajına sebep olmuştur. ABD bölgede kendisine yakın yönetimler kurmaya çalışmış, bölgede çıkarlarına uymayan ülkeleri ise 
Birinci Körfez Savaş'ında olduğu gibi askeri müdahale yoluyla sindirme yoluna gitmiştir.

Putin dönemiyle tekrar ekonomik canlanmanın yaşanması ve bölgesel güç olarak hareketlenen Rusya ise bölge politikalarında etkin olmaya çalışmış ancak 11 Eylül saldırıları ABD'ye bir anlamda yeni ve büyük avantajlar sağlamıştır. 11 Eylül ile birlikte ABD, demokrasi ve İnsan Hakları gibi kavramları bölgeye yaymak ve uluslararası terörizme karşı mücadele etmek adı altında harekete geçmiştir. Yaşanan 11 Eylül saldırıları bölgeye yayılmayı amaçlayan ABD'nin işini kolaylaştırmış ve bölge ülkelerine askeri müdahalede bulunmasına yasal bir gerekçe olarak görülmüştür. Bu süreci Afganistan ve Irak müdahaleleri izlemiş, sürece katılmayanın bölgede söz sahibi olma hakkını kaybedecek duruma geleceği düşüncesi batılı güçlerin ve Rusya'nın da bu süreçte olumlu ya da olumsuz yer almasına neden olmuştur. Buna karşın Orta Doğu'da süper güç ABD'nin karşısında var olabilmek için stratejik ortaklıkların da ön plana çıtığ görülmektedir. Rusya ve Çin'in ABD güdümlü İran'a yapılacak bir operasyona karşı çıkması bunun açık bir göstergesidir. ABD ve batı karşıtı İran yönetimini hedef alacak bir saldırı Rusya ve Çin'in çıarlarına ters düşmektedir. Bu süreçte Rusya ve Çin'in BM Güvenlik Konseyi daimi üyeleri olması da ellerindeki en önemli güç unsuru olarak ortaya çıkmaktadır.

Orta Doğu'nun enerji kaynaklarına bağlı durumda olan diğer bir güç ise $A B^{\prime}$ dir. $\mathrm{AB}$ ülkeleri petrol ve doğalgaz kaynakları sınırlı ülkelerdir ve gelişen ekonomilerinden dolayı enerjiye talepleri artmaktadır. Bu talebi karşılama da Orta Doğu özel önem teşkil etmektedir. Bu amaçla bölgede etkin olmaya çalışan $A B$, ekonomik işbirlikleriyle bölgeye ulaşmaya çalışmaktadır. Askeri alanda ise NATO güdümlü Libya'ya yapılan operasyonlar $\mathrm{AB}^{\prime}$ nin de bölgede gücünü göstermede çekinmeyeceğini, çıkarları doğrultusunda bölgede güç kullanabileceğini ortaya koymuştur.

Sonuç olarak enerjiye talebin giderek arttığı dünyamızda küresel güçlerin bölgeye olan ilgisinin önümüzdeki dönemde de artarak devam edeceği açıkça görülmektedir. ABD'nin bölge enerji kaynakları üzerindeki etkisine karşılık Rusya ve Çin bir eksen buna karşılık Fransa, Almanya gibi başat batılı güçler de diğer bir eksen olarak gözükmektedir. Ortak nokta ise her ülkenin kendi çıkarları doğrultusunda bölgede gerek ekonomik, gerek siyasi ve gereksede askeri müdahalelerde bulunabilme ihtimallerinin yüksek olduğudur. Orta Doğu'nun enerji kaynakları onun zenginliği olduğu kadar da makûs kaderini etkileyecek en önemli faktör olmaya 21. yüzyılda da devam edecek gibi gözükmektedir. 
Bölgenin önemli ülkelerinden biri olan Türkiye'nin de tüm bu gelişmelerin yanında ekonomik krizlerle boğuşan ve önemli ölçüde güç kaybeden batı dünyasının geleceğini iyi okuyup Orta Doğu politikalarında başta İran olmak üzere Rusya ve Çin'i yavaş yavaş merkeze alma zorunluluğu kendini göstermeye başlamıştır. Üretimin en stratejik girdisi konumunda bulunan enerji kaynakları açısından atılacak doğru adımlar ve kurulacak yeni stratejik ilişkiler çerçevesinde Türkiye 21. yüzyıldaki ekonomik gelişmeleri büyük oranda teminat altına almış olacaktır.

\section{Kaynakça}

Acar, Ç; Sertaç B,; Fevzi G,; ve Çiğdem M.;(2007), Petrol Ve Doğal Gaz, ODTÜ Yayıncllık, Ankara.

Ahmetbeyoğlu, A; Hayrullah C,; Yahya B; (2003), Irak Dosyası, Tarih ve Tabiat Vakfı Tatav Yayınları, İstanbul.

Akbaş, Z; (2011), “ABD'nin Orta Doğu Politikalarının

Sürdürülebilirliği ve Orta Doğu'da Güç Mücadelesi”,

Uluslararası Tarih Araştırmaları Dergisi, Ekim 2011 ABD ve

Büyük Ortadoğu ilişkileri özel sayısı,ss.1-18,

Alkin, K ve Sabit A,; (2006), Küresel Petrol Stratejilerinin Jeopolitik

Açıdan Dünya Ve Türkiye Üzerindeki Etkileri, İstanbul Ticaret Odası, İstanbul.

Arı, T; (2004), Geçmişten Günümüze Orta Doğu Siyaset Savaş ve Diplomasi, Alfa Yayınları., İstanbul.

Ayhan ,V; (2009), Ortadoğu ve Petrol İmparatorluk Yolu, Dora Yayınları, Bursa.

Bal, İ; (2008), ABD Politikaları ve Türkiye, Lalezar Kitabevi, Ankara.

Banks F. E.;(2000), Energy Economics: A Modern Introduction, Kluwer Academic Publishers, USA,

Davutoğlu, A; (2001), Stratejik Derinlik Türkiye'nin Uluslararası Kопити, Küre yayınları, İstanbul. 
Eden R. and etc.; (1982), Energy Economics Growth, Resources and Policies, Cambridge University Press,

ETKB; (1984),T.C Enerji ve Tabii Kaynaklar Bakanlığı, 1985 Enerji Politikası 1, Ankara.

Huntington, P. S., (1997), Medeniyetler Çatışması, (çev.) M. Yılmaz, Vadi Yayınları, Ankara.

Karaca, K; (2003), Dünyadaki Yeni Güç Çin Tek Kutuptan Çift Kutuba, IQ Sanat Yayıncılık, İstanbul.

Kraft J. and Kraft A.;(1978), “On the Relationship Between Energy and GNP", Journal of Energy and Development, Vol:3, Number:2,

Norton, R A.; (2000), Ortadoğu Politikaları ve Güvenlik, (Çev. Ceylan Tokluoğlu), Büke Yayınları, İstanbul.

Özel, P; (2003), Petrol Sanayiinde Dikey Bütünleşme Ve Türkiye'de Uygulanabilirliği, DPT, Ankara.

Parlar, S; (2003), Barbarlı̆̆ın Kaynă̆ı Petrol, Anka Yayınları, İstanbul.

Sevim, C., (2012), "Küresel Enerji Politiği ve Enerji Güvenliği", Journal Of Yaşar University, C. 7, S. 26, İzmir, ss. 4378-4391

Tellal, E; (2010), “Zümrüdüanka: Rusya Federasyonu'nun Dış Politikası", Ankara Üniversitesi SBF Dergisi,65,S,3,Ankara,ss.190- 236.

Üşümezsoy, Ş ve Şamil Ş,; (2003), Yeni Dünya Petrol Düzeni ve Körfez Savaşları, İnkılap Kitabevi, İstanbul.

Yergin, D; (2011), Petrol Para Ve Güç Çatışmasının Epik Öyküsü,(Çev. Kamuran Tuncay), Türkiye İş Bankası Kültür Yayınları, İstanbul. 


\section{İnternet Kaynakları}

Andersen, S. S., (2000), "EU Energy Policy: Interest Interaction and Supranational Authority", Arena Center For European Studies, http://www.sv.uio.no/arena/english/research/publications/arenapublications/w orkingpapers/working-papers2000/wp00_5. htm, (21 Nisan 2013).

BP; (2012), BP Energy Outlook, http://www.bp.com/liveassets/bp_internet/globalbp/STAGING/global_assets /downloads/O/2012_2030_energy_outlook_booklet.pdf (20 Nisan 2012).

BP; (2011), Statistical Review of World Energy, http://www.bp.com/liveassets/bp_internet/globalbp/globalbp_uk_english/re ports_and_publications/statistical_energy_review_2011/STAGING/local_ass ets/pdf/statistical_review_of_world_energy_full_report_2011.pdf (23 Nisan 2012).

Cardwell. D., and Krauss C., (2013), “Trucking Industry Is Set to Expand Its Use of Natural Gas", The New York Times, http://www.nytimes.com/2013/04/23/business/energy-environment/naturalgas-use-in-long-haul-trucks-expected-to-rise.html?ref=dianecardwell, $\quad$ (6 Mayis 2013).

DEKTMK, (2012), “Enerji Raporu 2011”, Dünya Enerji Konseyi Türk Milli Komitesi, http://www.dektmk.org.tr/upresimler/enerjirapor2012.pdf, (19 Mart 2013).

Eİ;(2010),U.S.EnergyInformationAdministration, http://www.eia.gov/countries/cab.cfm?fips=CH (27 Nisan 2012).

EİA;(2011),U.S.EnergyInformationAdministration, http://205.254.135.7/countries/cab.cfm?fips=IR, (27 Nisan 2012)

EPDK,(2012), Petrol Piyasası Daire Başkanlığı, Petrol Piyasası Sektör Raporu,Ankara.

http://www.epdk.gov.tr/documents/petrol/rapor_yayin/PPD_SektorRapor20 11.pdf (25 Nisan 2012)

Euractiv, (2009), "Russia Builds Baltic Oil Pipeline to Bypass Belarus", http://www.euractiv.com/energy/russia-builds-baltic-oil-pipelin-news-221925, (8 Nisan 2013). 
EUROSTAT;(2008),http://ec.europa.eu/dgs/energy_transport/figures /pocketbook/doc/2007/2007_energy_en.pdf(24 Nisan 2012).

EUROSTAT;(2012),http://epp.eurostat.ec.europa.eu/tgm/refreshTabl eAction.do?tab=table\&plugin $=1 \&$ pcode $=$ tgigs $360 \& l a n g u a g e=e n(24 \quad$ Nisan 2012).

IEA; (2010), International Energy Agency, Energy Statistics, http://www.iea.org/stats/pdf_graphs/29TPESPI.pdf (20 Nisan 2012).

IEA;(2011),International Energy Agency, statistical review of world energy full report, 2011, (10 Nisan 2012).

North-Stream, (2013), "Who We Are", http://www.nordstream.com/about-us/, (12 Nisan 2013).

SIPRI,(2011),http://milexdata.sipri.org/files/?file=SIPRI+milex+data+1 988-2011.xls(18.04.2011).

TPAO, (2010), Ham Petrol ve Doğalgaz Sektör Raporu, Ankara, http://www.tpao.gov.tr/tpfiles/userfiles/files/sektorraporu_2010.pdf (10 Nisan 2012). 